\title{
Cell-Mediated Responses to Human Metapneumovirus Infection
}

\author{
Marlies Ballegeer ${ }^{1,2}$ and Xavier Saelens ${ }^{1,2, *(D)}$ \\ 1 VIB-UGent Center for Medical Biotechnology, VIB, B-9052 Ghent, Belgium; marlies.ballegeer@vib-ugent.be \\ 2 Department of Biochemistry and Microbiology, Ghent University, B-9000 Ghent, Belgium \\ * Correspondence: xavier.saelens@vib-ugent.be
}

Received: 24 March 2020; Accepted: 12 May 2020; Published: 14 May 2020

check for updates

\begin{abstract}
Viruses are the most common cause of acute respiratory tract infections (ARTI). Human metapneumovirus (hMPV) frequently causes viral pneumonia which can become life-threatening if the virus spreads to the lungs. Even though hMPV was only isolated in 2001, this negative-stranded RNA virus has probably been circulating in the human population for many decades. Interestingly, almost all adults have serologic evidence of hMPV infection. A well-established host immune response is evoked when hMPV infection occurs. However, the virus has evolved to circumvent and even exploit the host immune response. Further, infection with hMPV induces a weak memory response, and re-infections during life are common. In this review, we provide a comprehensive overview of the different cell types involved in the immune response in order to better understand the immunopathology induced by hMPV. Such knowledge may contribute to the development of vaccines and therapeutics directed against $\mathrm{hMPV}$.
\end{abstract}

Keywords: human metapneumovirus; innate and adaptive immune response; evasion strategies

\section{Introduction}

Acute respiratory tract infections (ARTI) are the most common cause of symptomatic illness worldwide. Although some bacteria and fungi can cause ARTI, viruses are by far the most common cause of ARTI [1,2]. ARTI that are confined to the upper respiratory tract typically result in mild respiratory symptoms. However, when the infection spreads to the lungs, this can lead to life-threatening pneumonia. Two members of the Pneumoviridae family, namely, human respiratory syncytial virus (hRSV) and human metapneumovirus (hMPV), frequently cause viral pneumonia in infants and children ( $<$ five years of age), the elderly ( $>65$ years of age), and immune-compromised individuals [3-5]. hRSV, first isolated in 1956 from a colony of chimpanzees [6], is now estimated to be the most common cause of childhood pneumonia worldwide [7]. hMPV, first isolated from children in the Netherlands [3], is an important cause of bronchiolitis and pneumonia in children[8-11]. Several studies have shown that up to $95 \%$ of children infected with hMPV were previously healthy, indicating that young age is one of the major factors influencing disease severity $[12,13]$. Hospitalization rates due to hMPV infection are highest in the first five years, with a peak age between six and 12 months of age [12,14-19]. Interestingly, a significant fraction of ARTI that was first considered to have an unknown cause is now attributed to infection with hMPV, supporting early observations that hMPV had been circulating in the human population long before it was first isolated [3]. Supporting that, nearly $100 \%$ of people test positive for antibody reactivity in their blood by the age of 10, and almost all adults have serologic evidence of prior hMPV infection [3,20-22]. hMPV is classified into two major genetic lineages, hMPV A and B, that are further subdivided into lineages $\mathrm{A} 1, \mathrm{~A} 2, \mathrm{~B} 1$, and $\mathrm{B} 2[3,23,24]$. The circulation of the four genetic lineages of hMPV was confirmed in worldwide studies. Long-term retrospective studies conducted in the United States from 1981 to 2001 concluded that multiple lineages can circulate in the same period at a 
given location $[25,26]$. Co-circulation of both hMPV A and B genotypes has been documented both in children [27] and adults [28]. However, generally one lineage dominates a season, which varies year by year $[29,30]$. Studies in rodents and non-human primates show a high degree of cross-protection and -neutralization between different hMPV lineages [31]. However, studies using lineage-specific antisera of ferrets and Syrian golden hamsters have shown that homologous virus-neutralizing titers were significantly higher than titers against heterologous hMPV lineages and that the antigenic relatedness between viruses from two genetic lineages was relatively low [32,33]. These observations of limited cross-protection, together with reports of re-infections of macaques [34] and humans [35] with genetically distinct hMPV strains, might explain why it is possible that multiple lineages of hMPV can co-circulate.

hMPV is an enveloped negative-stranded RNA virus with a non-segmented genome of approximately13.3 kilobases. The viral genome comprises eight genes and codes for nine proteins: nucleoprotein $(\mathrm{N})$, phosphoprotein $(\mathrm{P})$, matrix protein $(\mathrm{M})$, fusion protein $(\mathrm{F})$, matrix-2 proteins $(\mathrm{M} 2-1$ and M2-2), small hydrophobic (SH) protein, glycoprotein (G), and large (L) polymerase protein (Figure 1). Together, the N, L, and P proteins form the viral replication complex. Interestingly, the gene order of hMPV is not only different from that of hRSV, but the virus also lacks the non-structural proteins NS1 and NS2 [3]. Three transmembrane surface glycoproteins are embedded in the lipid envelope: F, G, and SH. The G protein is important for the attachment of the virion to the host cell. The F protein mediates fusion of the viral and host cell membrane. The exact function of the SH protein remains elusive. The $\mathrm{F}$ protein sequence is relatively well-conserved between different $\mathrm{hMPV}$ genotypes compared to $\mathrm{G}$ and $\mathrm{SH}$ which are more variable [24,32,36,37]. In addition, when grafted into the genome of recombinant replication competent human parainfluenza viruses that were subsequently used to infect hamsters, hMPV F, but not G or SH, was shown to be able to induce neutralizing antibodies [38,39]. In the ribonucleoprotein complex, the viral RNA is entirely coated by the $\mathrm{N}$ protein, resulting in flexible helical nucleocapsids, which are also decorated with the $\mathrm{P}$ protein and can recruit the $L$ and M2-1 proteins. In negative-stranded RNA viruses, the viral nucleocapsid serves to protect the viral RNA from degradation and as a template for viral replication and transcription [40].

A.

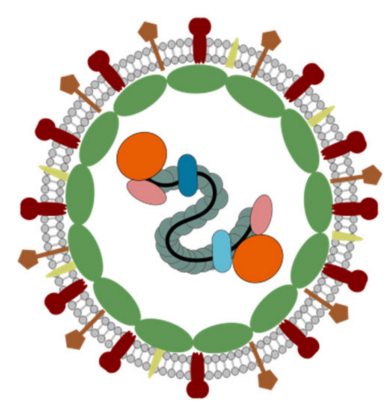

B.

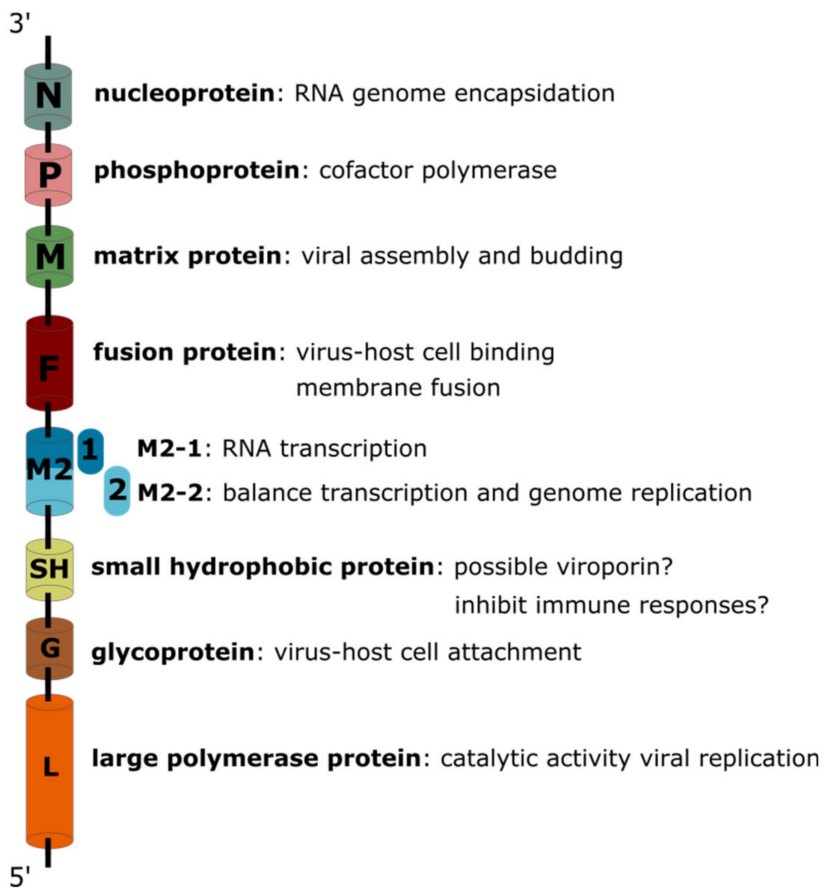

Figure 1. Human metapneumovirus (hMPV) virion structure with viral proteins and their function. Schematic representation of the hMPV viral particle (A) and viral genome with encoded proteins (B): nucleoprotein $(\mathrm{N})$, phosphoprotein $(\mathrm{P})$, matrix protein $(\mathrm{M})$, fusion protein $(\mathrm{F})$, matrix-2 proteins $(\mathrm{M} 2-1$ and M2-2), small hydrophobic (SH) protein, glycoprotein $(\mathrm{G})$, and large (L) polymerase protein. 
In general, when respiratory viruses break through the mucosal layer that lines the airway epithelial cells (AECs), dendritic cells (DCs) may already come into play, because dendrites of these cells can sample particles that are present in the airway lumen. DCs that take up virions, for example, can process viral proteins into peptides for antigen presentation. Upon DC migration to the regional draining lymph node, the processed viral antigen can be presented to CD4+ and CD8+ T cells. The activated effector $T$ cells with a matching $T$ cell receptor subsequently expand and travel to the lung parenchyma where they can eliminate the infected epithelial cells [41].

This well-established immune response is also crucial for hMPV clearance and antiviral defense, so when the immune system is compromised, hMPV can persist as has been observed in hematopoietic stem cell recipients [42,43]. Interestingly, hMPV has developed several mechanisms to circumvent the immune system (reviewed here and in [44]). hMPV infection induces a rather weak immune memory response, which helps to explain why recurrent infections during life are common $[35,45,46]$. Here, we provide a comprehensive overview of the different cell types involved in the immune response against hMPV infection and some new insights into the strategies the virus has developed to evade the host immune response.

\subsection{Airway Epithelial Cells (AECs)}

The major cell populations that can sense hMPV in an acute infection are AECs [47], alveolar macrophages $(\mathrm{AM} \varphi)$ [48], and DCs [49]. hMPV primarily replicates in the epithelial cells located in the upper (nasopharynx) and lower (lungs) respiratory tract [25,26,50-52]. The infection gives rise to airway epithelial injury and remodeling [53-55]. AECs are armed with pattern recognition receptors (PRRs) that can recognize pathogen-associated molecular patterns (PAMPs) such as viral RNA. PAMP recognition triggers signaling cascades that lead to transcriptional upregulation of cytokines and chemokines and regulate the inflammatory responses in the infected host [56]. In general, two major PRR pathways have been described that can recognize different viral products: (i) the RIG-I-like receptors (RLRs) retinoic-acid inducible gene I (RIG-I) and melanoma differentiation-associated 5 (MDA-5) and (ii) Toll-like receptors (TLRs) including TLR3, TRL4, and TLR7. hMPV infection of A549 cells, a human alveolar type II like epithelial cell line, induces both RIG-I and MDA-5 gene and protein expression [57]. In addition, A549 cells secrete a variety of cytokines and chemokines, as well as type I interferons (IFNs), upon hMPV infection [58]. Interestingly, although hMPV can directly induce RIG-I expression, type I IFNs enhance the induction [57]. Interestingly, RIG-I-dependent signaling, but not MDA-5, is necessary to induce an antiviral state in A549 cells and reduce viral replication. Only inhibition of RIG-I expression significantly reduces activation of interferon regulatory factors (IRFs), transcription factors, and production of type I IFNs [57]. It is important to note that RIG-I gene silencing resulted in incomplete abrogation of cellular responses and that other pathways are also involved. Bao et al. showed that TLR3 expression is induced in AECs upon hMPV infection [59]. However, inhibition of TLR3 expression does not affect $\mathrm{hMPV}$-induced chemokine gene expression in A549 cells [57]. Triggering of RIG-I and MDA-5 leads to the recruitment of a signaling complex to the outer membrane of mitochondria and activation of IRFs and subsequent IFN and interferon-stimulated gene (ISG) expression. Mitochondrial antiviral-signaling protein or MAVS has been identified as an adaptor protein in this signaling complex $[60,61]$ and plays an important role in hMPV-induced signaling in airway epithelial cells [57].

IFNs are potent antiviral cytokines which also have important roles in shaping the adaptive immune response [62]. IFNs can amplify the antiviral response and limit viral replication by inducing the expression of ISGs. Several in vitro studies have shown that different strains of hMPV induce the production of IFNs (type I, II, and III) in A549 cells and that this response relies on viral replication $[57-59,63,64]$. Schoggins et al. have catalogued several ISGs that might have an inhibitory effect on different DNA and RNA viruses [65]. The top hits for hMPV inhibition are CD9, HPSE, P2BY6, and interferon induced transmembrane protein 3 (IFITM3) [65]. Supporting that, McMichael et al. showed that the expression of IFITM3 inhibits hMPV infection in vitro by dysregulation of hMPV F 
protein-mediated cell to cell fusion [66]. In general, a viral infection induces IFN-dependent antiviral defense strategies in AECs. As a counteraction, viruses modulate this response via several mechanisms resulting in inhibition of IFN synthesis, affecting type I IFN responses and blocking the expression of ISGs [67]. hMPV has been reported to inhibit type I IFN signaling at different levels of the signaling cascade involving the regulation of signal transducer and activator of transcription 1 (STAT1), STAT2, Janus kinase 1 (Jak1), tyrosine kinase 2 (Tyk2), and surface expression of interferon alpha receptor subunit 1 (IFNAR1) [68,69]. In addition, the G protein has been reported to interact with RIG-I and to block RIG-I-dependent gene transcription and thus IFN production [70]. For a detailed overview of the interferon response upon hMPV infection in vitro, animal models and clinical settings, we refer to [71].

Triggering of PRRs does not only induce IFN expression, it also upregulates several pro-inflammatory genes activating the immune response, resulting in pulmonary inflammation and viral clearance. Chemokines are important cytokines that regulate the migration and activation of leukocytes including neutrophil, macrophages, and monocytes to the site of infection [72]. hMPV-infected AECs secrete an important array of pro-inflammatory chemokines carrying CC and CXC motifs [59]. CC-bearing chemokines include CCL2, CCL3, CCL4, and CCL5. CXC-bearing chemokines include CXCL1, CXCL2, CXCL3, CXCL8/IL-8, CXCL10, and CXCL11. CCL2 is an important chemoattractant for monocytes [73] whereas CCL3 and CCL4 recruit and activate neutrophils [74]. In a mouse model of hMPV infection, the majority of lung inflammatory cells are neutrophils and mononuclear cells including macrophages/monocytes during the first days of infection. However, in cotton rats, recruited monocyte/macrophage cell counts were lower [75]. In conclusion, the recruitment of monocytes to the lungs after hMPV infection has been described in hMPV infection animal models, but their importance has not been fully explored.

hMPV also induces expression of thymic stromal lymphopoietin (TSLP) and interleukin 33 (IL-33) in AECs in vitro [76]. Both cytokines activate DCs by inducing the expression of OX40L. TSLP-induced OX40L on DCs primes naïve CD4+ T cells to differentiate into Th2 cells [35,36]. TLSP-activated DCs in turn produce CCL17, an important Th2 enhancing chemokine and attractor of natural killer (NK) cells $[77,78]$. In lungs of hMPV-infected mice, the expression of TSLP and CCL17 was confirmed. Further studies based on genetic abrogation and immunological blocking of the TSLP-TSLPR pathway revealed that TSLP is one of the main causes of hMPV-induced lung inflammation, and, remarkably, also contributed to hMPV replication in mice [76]. More recently, Li et al. showed that only the pro-inflammatory long form of TSLP (IfTSLP) is induced by hMPV and that the levels of the short form (sfTSLP) with anti-inflammatory functions are not changed [79]. The lfTSLP induction depends on the activation of NF- $\mathrm{B}$ downstream of RIG-I and TLR3 and is facilitated by TANK binding kinase 1 (TBK1) [79]. In conclusion, by activating the TSLP pathway and creating a microenvironment that favors Th2 responses, hMPV might hamper or delay a more efficient antiviral Th1 response [76].

One may expect that viral infection of AECs will result in a gene expression profile with an innate immune signature. Indeed, several transcriptomic studies focused on the many upregulated genes that are involved in the initiation of pro-inflammatory and antiviral immune responses, including chemokines, cytokines, type I IFN, and interferon-inducible proteins [59,64,80]. However, other and more recent transcriptomic studies also show that metabolic genes and several mucins are upregulated, and cilium-associated genes are downregulated [63,81]. It is important to note that approximately $20 \%$ of the genes affected by hMPV infection are related to metabolic pathways. Moreover, most of the core metabolic enzymes are downregulated upon infection [82]. More specifically, hMPV infection causes tricarboxylic acid (TCA) cycle impairment and drives de novo fatty acid synthesis which has been shown to be necessary for replication of several viruses [83]. Another interesting observation was the fact that hMPV induced a progressive decrease of antioxidant enzyme (AOE) expression levels in AECs and the lungs of infected mice. Reduced AOE expression usually results in increased levels of oxidative stress markers illustrating an imbalance between reactive oxygen species production and antioxidant cellular defenses [59,84]. The transcription factor NF-E2-related factor or Nrf2 regulates antioxidant and cellular protective gene expression, mainly in response to oxidative stress [85]. A recent 
study suggests that $\mathrm{NrF} 2$-dependent genes affect viral replication, airway obstruction, clinical disease, and neutrophilia upon hMPV infection. Using Nrf2 KO mice, Ivancuic et al. showed that functional deficits in Nrf2 and inadequate AOE expression lead to viral-mediated oxidative stress and damage of the airways [86].

To limit viral replication and spreading, AECs may undergo programmed cell death or apoptosis to facilitate viral clearance $[87,88]$. Marsico et al. monitored the behavior of AECs during acute hMPV infection (based on the protocol of Bao et al. [58]) using A549 cells and showed massive cell death characterized by apoptotic nuclei and DNA fragmentation during the first three days and up to seven days post infection (dpi). Moreover, the caspase- 3 and -7 activity gradually increased up to 7 dpi, and a role for phosphorylation of the Wee1 kinase in the hMPV-driven apoptosis could be identified [89]. Interestingly, the caspase activity decreased at $14 \mathrm{dpi}$, and the residual epithelial cells at that time point seem to reverse the apoptotic process. It has indeed been described that prevention of apoptosis in virus-infected cells represents a critical step in establishing viral persistence. Therefore, a persistent virus has developed mechanisms to suppress apoptosis for a longer time to maintain a compartment of infected cells [90]. It is important to note that hMPV persistence has only been described in some mouse studies [54,91-93] and a few immunocompromised patients of which some had no symptoms [42,43,94]. Additionally, hMPV persistence has been described in vitro in A549 cells by Marsico et al. [89]. This study showed that at $14 \mathrm{dpi}$, the hMPV-infected cells were still metabolically active which could represent the beginning of coexistence between AECs and hMPV and thus transition from acute to persistent infections. In general, viruses may be able to persist by interfering with the induction of apoptosis. Supporting that, chronic hMPV infection in AECs increased expression of the anti-apoptotic Bcl-2 protein, which overthrows the apoptotic program [89].

\subsection{Alveolar Macrophages $(A M \varphi)$}

The resident macrophages of the lungs or alveolar macrophages $(\mathrm{AM} \varphi)$ are localized in the airspaces within alveoli. From this unique position $\mathrm{AM} \varphi$ are able to respond quickly to insults in the lower airways. Under homeostatic conditions, the $\mathrm{AM} \varphi$ are kept in a suppressive state by the lung environment in order to prevent inappropriate inflammatory responses to harmless antigens. However, upon viral infection, the expression of the negative regulators declines rapidly and the lung environment is reshaped. Coupled with the detection of viral antigens and exposure to pro-inflammatory mediators, $\operatorname{AM} \varphi$ adopt a pro-inflammatory phenotype and initiate the innate immune response and viral clearance [95]. AM $\varphi$ are the primary source of inflammatory and immunomodulatory cytokines in the lungs. They play a pivotal role against both viral and bacterial pathogens and their depletion severely impairs the host response [96,97]. AM $\varphi$ are the major cellular source of hMPV-induced type I IFNs IFN- $\alpha$ and $-\beta$ but also other pro-inflammatory cytokines such as tumor necrosis factor alpha (TNF- $\alpha$ ) and IL-6 in the lungs. Depletion of AM $\varphi$ by clodronate-loaded liposomes (L-CL2MBP) before hMPV inoculation enhanced viral replication, pulmonary inflammation, and airway disease [48]. Interestingly, treatment with L-CL2MBP after hMPV infection did not alter lung viral replication (Table 1). The results of these depletion studies imply that $\mathrm{AM} \varphi$ are critical in the early phase of viral entry and that the virus directly targets $\mathrm{AM} \varphi$. This hypothesis was supported by the fact that hMPV is able to replicate in $\mathrm{AM} \varphi$ isolated from bronchoalveolar lavage (BAL) fluid, ex vivo, although the infection is less efficient than in AECs [48]. A recent study by Li et al. shows that infection with hMPV downregulates $\mathrm{C} / \mathrm{EBP} \alpha$, a transcription factor critical for the expression of the homeostatic effector molecule cyclic adenosine monophosphate or cAMP. The suppressive effect on cAMP could be one of the events in $\mathrm{AM} \varphi$ reprogramming in response to hMPV infection [98]. 
Table 1. Studies showing the importance of different cell types involved in hMPV infection.

\begin{tabular}{|c|c|c|c|c|c|c|}
\hline Cell Type & Strategy for Cell Type Depletion & Time of Depletion & Lung Viral Load & $\begin{array}{l}\text { Lung Inflammation } \\
\text { and Histopathology }\end{array}$ & Mouse Strain & Reference \\
\hline \multicolumn{7}{|l|}{$\begin{array}{l}\text { Innate } \\
\text { Immunity }\end{array}$} \\
\hline \multirow[t]{2}{*}{$\operatorname{AM} \varphi$} & L-CL $\mathrm{CL}_{2} \mathrm{MBP}$ liposomes & Before hMPV inoculation & Decreased & Decreased & $\mathrm{BALB} / \mathrm{c}$ & [48] \\
\hline & & After hMPV inoculation & Unchanged & Not investigated & $\mathrm{BALB} / \mathrm{c}$ & [48] \\
\hline \multirow{2}{*}{ Neutrophils } & & & Unchanged & Increased & $\mathrm{BALB} / \mathrm{c}$ & [76] \\
\hline & anti-Ly6G monoclonal antibody & Before hMPV inoculation & Decreased & Decreased & $\mathrm{BALB} / \mathrm{c}$ & [99] \\
\hline \multirow{2}{*}{ NK Cells } & Anti CD49b/Pan NK cell antibody & Before hMPV inoculation & Increased & Not investigated & $\mathrm{BALB} / \mathrm{c}$ & [91] \\
\hline & Anti NK1.1 antibody & Before hMPV inoculation & Unchanged & Unchanged & C57BL/6 & [100] \\
\hline NKT Cells & CD1d-/- mice & Before hMPV inoculation & Unchanged & Unchanged & $\mathrm{C} 57 \mathrm{BL} / 6$ & [100] \\
\hline \multicolumn{7}{|l|}{$\begin{array}{l}\text { Adaptive } \\
\text { Immunity }\end{array}$} \\
\hline \multirow{2}{*}{ T Cells } & Anti CD4 and anti CD8 antibody & Before hMPV inoculation & Increased & Decreased & $\mathrm{BALB} / \mathrm{c}$ & [101] \\
\hline & Anti CD3 $\varepsilon+$ anti $\alpha \beta T C R$ antibody & Before hMPV inoculation & Increased & Not investigated & $\mathrm{BALB} / \mathrm{c}$ & [91] \\
\hline \multirow{2}{*}{ CD4+ T Cells } & Anti CD4 antibody & Before hMPV inoculation & Unchanged & Decreased & $\mathrm{BALB} / \mathrm{c}$ & [101] \\
\hline & & Throughout hMPV infection & Increased & Increased & C57BL/6 & [102] \\
\hline \multirow{2}{*}{ Tregs } & FoxP3 ${ }^{\mathrm{DTR}}$ mice & Before hMPV inoculation (early) & Increased & Increased & C57BL/6 & [102] \\
\hline & & After hMPV inoculation (late) & Unchanged & Increased & C57BL/6 & [102] \\
\hline \multirow{3}{*}{ CD8+ T Cells } & Anti CD25 antibody & Before hMPV inoculation & Decreased & Not investigated & C57BL/6 & {$[102]$} \\
\hline & Anti CD8 antibody & Before hMPV inoculation & Unchanged & Decreased & $\mathrm{BALB} / \mathrm{c}$ & [101] \\
\hline & $\begin{array}{l}\text { Adoptive transfer hMPV specific } \\
\text { CTLs in Rag1 } 1^{-/-} \text {mice }\end{array}$ & Before hMPV inoculation & Decreased & Not investigated & $\mathrm{BALB} / \mathrm{c}$ & [103] \\
\hline$\gamma \delta \mathrm{T}$ Cells & $\begin{array}{c}\text { TCR- } \delta \text { KO mice } \\
\text { (B6.129P2-Tcrd } \\
\text { tm1Mom/J) }\end{array}$ & Before hMPV inoculation & Not investigated & Decreased & C57BL/6 & [99] \\
\hline
\end{tabular}

hMPV = human metapneumovirus; $\mathrm{AM} \varphi=$ alveolar macrophages; $\mathrm{NK}=$ natural killers cells; $\mathrm{NKT}=$ natural killer T; $\mathrm{CTL}=$ cytotoxic $\mathrm{T}$ lymphocytes; Tregs $=$ regulatory T cells; TCR = T

cell receptor; $\mathrm{CD}=$ cluster of differentiation; $\mathrm{KO}=$ knockout; Rag = recombination activating gene; Ly6G = lymphocyte antigen 6 complex, locus $\mathrm{G}$. 


\subsection{Neutrophils}

One of the first type of cells to arrive at the site of respiratory virus infections are neutrophils that specialize in the elimination of infected cells and clearance of microbial pathogens, dead cells, and debris [95]. In addition to their cytotoxic function, they also play a critical role in the innate and adaptive immune response by initiating crosstalk between resident and recruited immune cells including DCs and T cells. The secretion of cytokines and chemokines but also MHC molecules initiates this pivotal crosstalk [104]. It is important to note that, in general, respiratory viruses are not able to infect neutrophils productively. However, these cells can possibly phagocytose virions and apoptotic bodies that contain virus-derived gene products but this has not been described for hMPV [105]. Generally, neutrophils migrate to the site of infection at early time points and their potent but non-specific cytotoxic activity is short-lived. It is important that sufficient neutrophils are recruited in order to control virus dissemination but an excessive neutrophil response can be detrimental for the host. Therefore, neutrophils undergo apoptosis, and the apoptotic bodies and debris they leave behind are cleared by macrophages [95].

The fast influx of neutrophils upon hMPV infection has been well documented in animal studies. In mouse BAL fluid, a significant neutrophilia was observed within the first three days of infection. Moreover, neutrophil counts peaked on day one to two post-infection but decreased gradually starting on day four until day seven (reviewed by Cheemarla et al. [106]). Similar to what is seen in animal studies, hMPV infection is associated with neutrophil influxes in the airways of infected infants. Moreover, high cytotoxic neutrophil infiltration and high amounts of their degranulation products were strongly associated with an increased airway tissue injury [107]. The high neutrophil numbers positively correlated with the high expression levels of chemokines including KC (in mice [75]) and IL-8 (in infants [20]). Interestingly, in a first study where depletion of neutrophils was achieved by an anti-mouse Ly6G-specific monoclonal antibody [108], both inflammation and, surprisingly, lung viral loads were significantly reduced (Table 1) [76]. These results suggest that the recruitment of neutrophils in the airways supports viral replication albeit via an unknown mechanism. In contrast, a more recent study, with the same monoclonal antibody, showed an increased pulmonary inflammation and more severe clinical disease in neutrophil-depleted mice [99]. In this study, neutrophils did not contribute to lung viral clearance since no difference was observed in lung viral titers in the presence or absence of neutrophils (Table 1) [76]. The different outcomes of the two mouse studies can be explained by the difference in the administration scheme of the anti Ly6G antibody or the different hMPV strains used for infection. It is also important to note that during severe lung inflammation, a heterogeneous neutrophil population with distinct activation profiles and different effects on $\mathrm{T}$ cells characterize the systemic and local responses [109]. Therefore, one subset of mature neutrophils can clear infection and activate the immune system whereas others induce immunosuppression [110,111].

During hMPV infection, the G protein contributes to the recruitment of neutrophils. The exact mechanism still needs to be unraveled but potentially involves the inhibition of IFN responses by the $G$ protein [112]. The G protein has an inhibitory effect on RIG-I mediated activation of IFN- $\alpha$ and IFN- $\beta$ production $[69,70$ ] and inhibits the production and activation of IFN- $\lambda$ [113]. Inhibition of IFN signaling would lead to higher levels of chemokines and higher neutrophil numbers in the lung. Indeed, infection with recombinant hMPV that lacks the $G$ gene is associated with a reduced expression of TNF- $\alpha$ and IL-17, both known to promote expression of neutrophil chemotactic cytokines [112]. Although it is not known if other hMPV proteins have an effect on neutrophil function, it is likely that proteins that interfere with the IFN pathway such as the $\mathrm{SH}$ and M2-2 proteins will have an impact on neutrophil recruitment.

\subsection{Dendritic Cells (DCs)}

Respiratory tract DCs are present within the airway epithelium, submucosa, and lung parenchymal tissue under normal, resting conditions. They are highly likely to encounter virions because of their strategic location at the site of virus entry where they can sample antigens throughout the upper and 
lower respiratory tracts [114]. Upon infection, DCs can be activated directly by the virus through PRRs or indirectly by pro-inflammatory chemokines and cytokines released by AECs or other resident immune cells [115]. Activated DCs can migrate to the draining lymph nodes where they activate the adaptive immune response or they can stay in the lungs and promote immune responses locally. Plasmacytoid DCs (pDCs) play an essential role in the initial sensing of viral pathogens and initiation of immune response predominantly via the production of type I IFNs. Conventional DCs (cDCs) are mostly associated with the lung epithelium and migrate to the draining lymph nodes in the first days after infection where they function as antigen presenting cells (APCs) [95].

The initiation of the immune response via the secretion of IFNs, chemokines, and other cytokines but also the upregulation of a variety of costimulatory molecules and receptors or cell maturation is crucial for priming virus-specific CD4+ $\mathrm{T}$ cells and to initiate the antiviral response. Two groups have shown that hMPV can infect both cDCs and pDCs [49,114,116,117]. Although hMPV infection of DCs results in the expression of viral proteins, no major cytopathic effects such as syncytia formation or massive apoptosis were observed [49]. In addition, hMPV infection in both DC subtypes failed to induce a limited production of IFN- $\alpha$ [117]. Both TLR7 and MyD88 are essential for the secretion of type I IFNs by hMPV-infected pDCs [118,119]. Importantly, hMPV infection in DCs also induces the expression of several microRNAs (miRs) such as hsa-miR-182-5p and hsa-miR-4634. Although several microRNAs are believed to be known regulators of DC functions, including maturation, antigen presentation, and cytokine production, no link between the target genes of the hMPV-induced miRNAs and DC function has been found [120,121].

Despite the fact that hMPV-infected DCs showed a mild upregulation of co-stimulatory molecules on their surface, they fail to activate specific naïve $T$ cells efficiently [114,122,123]. Priming of hMPV-specific CD4+ T cells by DCs is a critical process in the induction of an antiviral response so naturally, hMPV seems to have developed several mechanisms to impair these functions of DCs [116,123].

To maintain efficient virus growth, hMPV has developed different strategies to minimize host IFN production. It is important to note that some of the studies described gave conflicting results, and there is still no consensus about the interactions between hMPV proteins and different host factors associated with the immune response. When investigating activation of IFN pathways upon hMPV infection, it is important to keep in mind that in vitro passage of hMPV may lead to the accumulation of so-called defective interfering (DI) particles [124]. DIs arise spontaneously when virus are passaged at high multiplicity of infection (m.o.i). in mammalian cell lines due to errors made by the replicase complex and consist of virions with partially deleted viral genomes [125]. Therefore, the presence of DIs could possibly explain the discrepancy in the reported results concerning IFN induction.

The $\mathrm{G}$ and $\mathrm{SH}$ proteins have been considered for a long time as non-essential proteins for hMPV replication, illustrated by the observation that recombinant $\mathrm{hMPV}$ viruses lacking either $\mathrm{G}$, SH or both genes can replicate efficiently in vitro and in vivo [80,126-128]. However, Le Nouën et al. showed that DCs infected with hMPV mutants that lack both the SH and G genes had an increased maturation rate and were able to prime naïve $T$ cells [122]. In addition, Kolli et al. suggested that $G$ promotes the inhibition of TLR4 signaling in DCs, which affects type I IFN secretion [129]. The G protein has also been reported as an interferon antagonist in AECs by Bao et al. [70]. Unfortunately, using siRNA against the G gene, Preston et al. were unable to confirm these results [130], so the question if the G protein interferes with the IFN response remains unanswered for AECs. One group showed that hMPV uses the SH protein to interfere with the TLR7/MyD88 pathway, resulting in the inhibition of type I IFN induction in pDCs $[118,131]$. Supporting an inhibitory role for SH, Hastings et al. showed that transient expression of the hMPV SH protein was able to prevent IFN-induced STAT1 phosphorylation in Vero cells. Additionally, infection with a recombinant hMPV strain lacking SH resulted in phosphorylation of STAT1 at the same level as uninfected cells [132]. In contrast, de Graaf et al. were unable to identify any function of $\mathrm{SH}$ in the context of viral replication or immune response in vitro in the host cell using an hMPV mutant lacking SH [80]. In addition, infection with recombinant hMPV 
that lacks SH presented no difference in viral kinetics and pathogenesis in a rodent model [126] and minimal attenuation in non-human primates [133]. In addition to the well-studied G and SH proteins, other viral proteins have been described to mediate hMPV immune evasion. A study by Ren et al. indicated that DCs infected with an hMPV mutant lacking the M2-2 protein produce higher amounts of MyD88-dependent genes including cytokines, chemokines and type I IFNs [134]. More specifically, M2-2 blocks the TLR7/9 dependent signaling pathway by suppressing IRF7 homodimerization through partial inhibition of IRF7 phosphorylation [135]. Two putative PDZ binding motifs in M2-2 play a major suppressive role in cellular innate immunity both in vitro and in vivo [136,137]. Infection of mice with reverse engineered hMPV virus with mutations in the M2-2 PDZ-binding motif induced higher DC maturation and recruitment of DCs and T cells in the lungs. These in vivo results highlight the potential for modification of M2-2 PDZ-binding motifs in order to overcome poor mucosal innate immunity upon hMPV infection [138].

\subsection{Natural Killer Cells (NKs)}

Natural killer (NK) cells respond to viral infection mainly by killing virus-infected cells but also by mediating the adaptive immune response. NK cells are perfectly equipped to distinguish normal cells from virus-infected cells. They express a specialized repertoire of both inhibitory and activating receptors regulating their activity. A large family of inhibitory receptors is able to recognize self-ligands such as MHC class I. In contrast, the number of different NK-activating receptors is limited. In humans, the most important activating NK cell receptors are NKp46, which belongs to the natural cytotoxicity receptors (NCR), and the NKG2D receptor that interacts with stress-induced ligands such as MICA and MICB $[139,140]$. NKp46 is the only NCR member that has a mouse orthologue named Ncr1. In addition to their direct cytotoxic effect via the release of cytotoxic granules, NK cells also increase cytotoxic T lymphocyte (CTL) activity via the production of IFN- $\gamma$ [141].

The role of NK cells in the antiviral response against hMPV infection appears to be mouse strain dependent. In both BALB/c and C57BL/6 mouse strains, NK cells are recruited to the lungs upon hMPV infection $[91,92,100,142]$. Moreover, the recruited NKs are activated, as indicated by the increased release of cytotoxic granules [100,142]. However, depletion of NK cells in BALB/c mice increases the lung viral titers [91] but no effect on viral titers has been seen in C57BL/6 mice (Table 1) [100]. It is important to note that NK1.1 antibody treatment depletes not only NK cells but also NKT cells. NKT cells embody a mixed population of T cells that possess killing properties of both NK and T cells and form a bridge between the innate and adaptive immune system. During viral infections, NKT cells exert effector functions but also regulate immune responses in order to limit lung inflammation [41]. Interestingly, a recent study by Gaya et al. showed that NKT cells promote B cell immunity during viral infections via the release of IL-4 [143]. To exclude the fact that the effects with the NK1.1 antibody might be due to NKT cell depletion, CD1d-deficient mice [144] were infected with hMPV. These mice lack NK1.1+ NKT cells but have normal NK cell numbers and have similar viral titers as NK1.1 antibody-treated mice upon hMPV infection (Table 1) [100]. Together, the mouse studies performed by Wen et al. exclude a role for NK and NKT cells in HMPV infection [100].

Upon hMPV infection, the expression of ligands for the activating receptors NKp46 and NCR1 increased [145]. Surprisingly, hMPV proteins do not appear to be recognized by the activating receptors and it remains unclear what the ligand of hMPV-infected cells is. As it is the case for other immune cells of the innate system, hMPV presumably benefits from the avoidance of recognition by NK cells. One possible mechanism is through downregulation of the stress ligand MICA, one of the major ligands of the activation receptor NKG2D and via upregulation of MHC class I, a ligand of the inhibitory receptor [145]. It is also likely that both the G and SH proteins of hMPV inhibit the recruitment of NK cells as these proteins affect the profile of chemokines produced after infection. 1.6. T cells

Conventional T cells play an important role in the control of hMPV replication in the lung during both the early and late phase of hMPV infection. When the total $\mathrm{T}$ cell population is depleted in mice, increased viral replication in the lung is observed (Table 1) [91]. In mouse models of hMPV, the number 
of both CD4+ and CD8+ T cells increased on day four and peaked on day six or eight, respectively. Interestingly, the levels were still elevated two weeks after infection [101]. In hMPV-infected mice, depletion of CD4+ and CD8+ T cells resulted in significantly higher body weight compared to control-treated hMPV-infected animals. The effect was most pronounced when CD4+ T cells were depleted, and no further protection was observed when both cell types were depleted simultaneously (Table 1) [101]. Surprisingly, depletion of CD4+ T cells or CD8+ T cells alone reduces lung pathology without affecting the viral load. Depletion of both subsets did result in higher viral titers, showing that both CD4+ and CD8+ T cells are necessary for clearing the primary infection in the lungs. Together, these data show that CD4+ or CD8+ T cells play an antiviral role by themselves, but the two subsets combined are more effective in the eradication of hMPV from the lungs. In order to evade the immune response, hMPV delays CTL responses [92]. In combination with an abnormal $\mathrm{T}$ helper response induced by hMPV-infected DCs, this results in poor clearance of the virus in the lungs [92].

Over the last years, the interest in the role of non-conventional $\mathrm{T}$ cells in immune homeostasis and during infections has increased. Non-conventional T cells, including $\gamma \delta \mathrm{T}$ cells, differ from conventional $\mathrm{T}$ cells in many ways and are important in bridging the innate and adaptive arms of the immune system. Their ability to exert effector functions soon after activation makes them, in contrast to conventional $\mathrm{T}$ cells, important in the early phase of infection. Unfortunately, due to their limited receptor diversity, they recognize conserved, non-peptide antigens [146]. Interestingly, when neutrophils were depleted in hMPV-infected mice, no difference in the number of CD4+ T and CD8+ T cells in the lung was observed; only a significant increase in lung $\gamma \delta \mathrm{T}$ cells was reported [99]. Under normal conditions, low numbers of $\gamma \delta \mathrm{T}$ cells reside in the lung in close proximity to epithelial mucosa. These cells are ideally located to participate in the first line of defense against infection [90]. After hMPV infection, the number of these non-conventional $\mathrm{T}$ cells increased after five days and the levels remained high after 15 days. In addition, TCR $\delta$ KO mice showed decreased pulmonary inflammation upon hMPV infection, supporting an immune suppressive role of $\gamma \delta \mathrm{T}$ cells in the hMPV-induced inflammatory response (Table 1) [99].

\subsubsection{CD4+ T Cells}

Early studies in BALB/c mice reported a Th1 response in the first week after hMPV infection, which controls initial virus replication. At later time points, polarization towards a Th2 immune response occurs and facilitates viral persistence [91,92]. The observed Th1 phenotype in mice correlates with the cytolytic activity of peripheral blood mononuclear cell (PBMCs) isolated from adults infected with hMPV and the predominant Th1 response generated in infected infants $[147,148]$. More recently, Douville et al. could not distinguish Th1 responses in the first week of hMPV infection in mice and concluded that mixed Th1 and Th2 responses mediate the immune reaction [149]. It is now clear that hMPV induces a complex $\mathrm{T}$ cell response, which is not well characterized and might include a mixed Th1/Th2 response. Independent of their phenotype, CD4+ T cells produce an inefficient IFN- $\gamma$ response when activated with hMPV-infected PBMCs in vitro [149]. The observed impairment of T cell immunity upon hMPV infection is most likely due to impaired functions of hMPV-infected DCs. Indeed, in vitro studies have shown that the $\mathrm{SH}$ and/or $\mathrm{G}$ proteins reduce $\mathrm{CD} 4+\mathrm{T}$ cell proliferation in an assay where they are co-cultured with hMPV-infected DCs [122].

A specific subset of CD4+ T cells, called regulatory $\mathrm{T}$ cells or Tregs, are master regulators of the immune system and immune homeostasis by engaging multiple mechanisms. Tregs can inhibit effector cell function and proliferation through the expression of inhibitory cytokines such as transforming growth factor beta (TGF- $\beta$ ) and IL-10. In addition, Tregs can adjust DC function via interaction of receptors such as cytotoxic T-lymphocyte-associated protein 4 (CTLA-4) and programmed cell death protein 1 (PD-1) with their ligands [150]. In response to hMPV, Tregs accumulate in the lungs of mice and are activated [102]. The Tregs responding to hMPV are most likely derived from naïve CD4+ T cells and do not have a thymic origin based on the low expression of markers to phenotype thymic Tregs. Interestingly, Rogers et al. demonstrated the importance of timing in the depletion of Tregs in 
the course of hMPV infection [102]. hMPV infection in FoxP3 ${ }^{\mathrm{DTR}}$ mice depleted of Tregs resulted in lower peak virus titers due to more effective anti-viral CD8+ T cells responses but was also associated with increased histopathology. It is important to note that the magnitude of the hMPV-specific CD8+ $\mathrm{T}$ cell response was unaltered. In contrast, depletion of Tregs immediately before infection by using an anti-CD25 antibody led to impaired DC and CD8+ T cell migration and delayed virus clearance (Table 1) [102]. In addition, absence of Tregs in the priming stage of infection skewed CD4+ T cells towards a Th2 phenotype. However, it was not studied in detail what the implications on virus-specific $\mathrm{T}$ cells were. Rogers et al. describes an important role for Tregs in priming the immune response. However, after the immune response has been initiated, Tregs are not essential and can even have detrimental effects [102]. The effect of hMPV infection on Tregs was also visible in a study with IL-17 deficient mice which have a defect in IL-17 production, leading to an immune response that is dominated by FoxP3+ Tregs. hMPV-infected IL-17 KO mice did not have altered lung viral titers or different lung inflammation scores compared to wild type mice [151]. Interestingly, infected IL-17 KO mice had an increased percentage of Tregs compared to mock-treated IL-17 KO mice and reduced percentages of Th1 and Th2 in the BAL fluid. It is important to note that the amount of Tregs between IL17 KO and WT mice was also different in the absence of hMPV. However, no increase after hMPV infection was seen in WT mice, suggesting that the imbalance between Tregs and Th17 worsens upon hMPV infection [151].

\subsubsection{CD8+ T cells}

Virus-specific CD8+ T cells can selectively eliminate infected cells. Following peak expansion, the CD8+ T cells numbers shrink and a memory population of virus-specific CD8+ T cells remains in the lungs [41]. hMPV infection results in the accumulation of hMPV-specific cytotoxic and IFN- $\gamma$ positive effector cells in both the airways and lungs seven days post infection. As expected, the presence of CTL activity correlated with the induction of IFN- $\gamma$ positive CD8+ T cells. A recent study by Tzannou et al. showed that hMPV-reactive T cells exist in the peripheral blood of healthy and immune-compromised subjects, although the levels were low and these specific $\mathrm{T}$ cells needed to be expanded first. In addition, they identified a hierarchy of immunodominance based on a number of donors who responded positively to hMPV antigens. It is interesting that the $\mathrm{F}$ protein was recognized by $97 \%$ of the donors followed by N, M2-1, M, P, L, P, and SH in that particular order of dominance [152].

Despite the fact that CD8 + T cells secrete IFN- $\gamma$ and kill infected cells in vitro, they fail to clear viruses in the airways in vivo. Studies by Erickson et al. show that CD8+ T cells become exhausted and upregulate PD-1 and fail to respond when restimulated with viral antigens [153]. Upon hMPV infection, PD-1-mediated pulmonary CD8+ T cell impairment occurred rapidly, already by day seven, and continued for several weeks after viral clearance [153]. Exhausted CD8+ T cells upregulate PD-1 in an antigen-dependent manner, so one way to prevent impairment is CD8+ T cell migration outside the infected lung to escape antigen-driven TCR signaling. In a re-infection model of hMPV, using $\mu \mathrm{MT}$ mice that lack B cells, impairment of memory CD8+ T cells was also observed, and the expression of PD-1 was upregulated. Blockade of PD-1 signaling restored CD8+ T cell function in the lung and enhanced hMPV control in both primary infection and re-infection $[153,154]$. The exhausted phenotype was also observed in IFNAR1 deficient mice but the phenotype was linked to upregulation of another inhibitory receptor, i.e., Tim3, since the expression of PD-1L is driven by IFN signaling [155].

\subsection{B Cells}

An important step in the control of viral infections is the production of virus-specific antibodies by B cells. These antibodies can neutralize, opsonize and inactivate virions or facilitate killing of infected cells. In order to prevent virus dissemination, the spread of infectious virions to neighboring cells needs to be controlled. Neutralizing antibodies can block the activity of viral surface proteins and prevent free virions from invading uninfected cells [95]. hMPV-specific antibodies are produced after the first infection in childhood and are still detectable after 20 years [3,20-22]. The predominant antibodies are 
directed against the F protein of hMPV. There is an inverse correlation between the levels of anti-hMPV antibodies and susceptibility to hMPV infection [156]. It is important to note that the hMPV-specific antibody response cannot effectively clear the virus, and hMPV is able to persist in the lungs, even in the presence of neutralizing antibodies [91,92]. Therefore, control of hMPV is partly mediated by cytotoxic T lymphocytes and NK cells [91]. The humoral response following natural infection is not sufficient to prevent re-infections. The interplay between the humoral and cell-mediated adaptive response is nicely demonstrated by the fact that production of neutralizing antibodies depends on CD4+ T cells since antibody levels are undetectable in mice depleted of CD4+ T cells [101].

\section{Conclusions}

One crucial aspect of the development of vaccines or therapeutics is the knowledge of host immune responses to hMPV infection and understanding of the immunopathology induced by the virus. In this review we focused on the different cell types that are involved in the immune response to hMPV infection and their contribution to hMPV replication and pulmonary inflammation. (Figure 2 and Table 1). Although a plethora of immune cells are involved in the immune response evoked by hMPV infection, the major cell populations that can sense hMPV in an acute infection are AECs, $\operatorname{AM} \varphi$, and DCs. Because of their unique location, these cells come in first contact, resulting in a first antiviral response characterized predominately by IFN production. Instantly, hMPV tries to counteract the response via several immune repressive mechanisms mainly mediated by its surface proteins $G$ and SH. Since the discovery of hMPV two decades ago, numerous new insights into the interaction between host and hMPV have been described. Unfortunately, there are several studies with conflicting results and up to now the roles of the $\mathrm{G}$ and $\mathrm{SH}$ proteins as antagonists of the immune responses remain unclear. In the future, it will be necessary to further investigate these interactions in more detail. In addition to mediators of the innate immune system, T cells, both CD4+ and CD8+ T cells, play a crucial role in the clearance of hMPV. Not surprisingly, hMPV has also evolved ways to delay the cytotoxic $\mathrm{T}$ cell response and viral clearance by impairing DC cell function. Further, CD8+ T cells become exhausted and upregulate PD-1 and fail to respond when restimulated with hMPV.

In order to be able to replace symptomatic treatment with hMPV-targeted therapies, further research is also needed into the replication cycle of hMPV. For example, a recent report shows that the formation of cytoplasmic inclusion bodies is required for hMPV genome replication and transcription [157]. Additionally, Pan et al. recently resolved the structure of the polymerase phosphoprotein complex [158]. These new observations are crucial in understanding hMPV biology and can lead to the development of new therapeutic strategies. In addition, a vaccine that can prevent disease caused by hMPV infection is highly desirable. Vaccine development for hMPV is, however, challenging because the antibody response induced by natural infection wanes over time [156] and the memory response in the host is weak [149]. Re-infections with hMPV are thus common in both children and adults. Vaccination strategies that merely aim to induce robust virus-specific neutralizing antibody responses should therefore aim to induce long-lasting immunity, which may be achievable with certain adjuvants $[159,160]$. In addition, the development of a CD8+ T cell-mediated vaccine could be pursued whether or not in combination with the induction of neutralizing antibodies. In order to include CD8+ $\mathrm{T}$ cell responses within a future vaccine strategy, more research is definitely needed, especially into the balance between cell-mediated protection and immunopathology. Furthermore, $\mathrm{T}$ cell impairment may represent a barrier to vaccination for ARTI, but pharmacologic restoration of $\mathrm{T}$ cell function by using, for example, PD-1 blockers, can have detrimental effects in the lungs as well [161].

The human respiratory system is a playground for hMPV. Ultimately, it may take a combination of a directly acting antiviral agent and a host response-modulating drug to control severe disease caused by hMPV. 


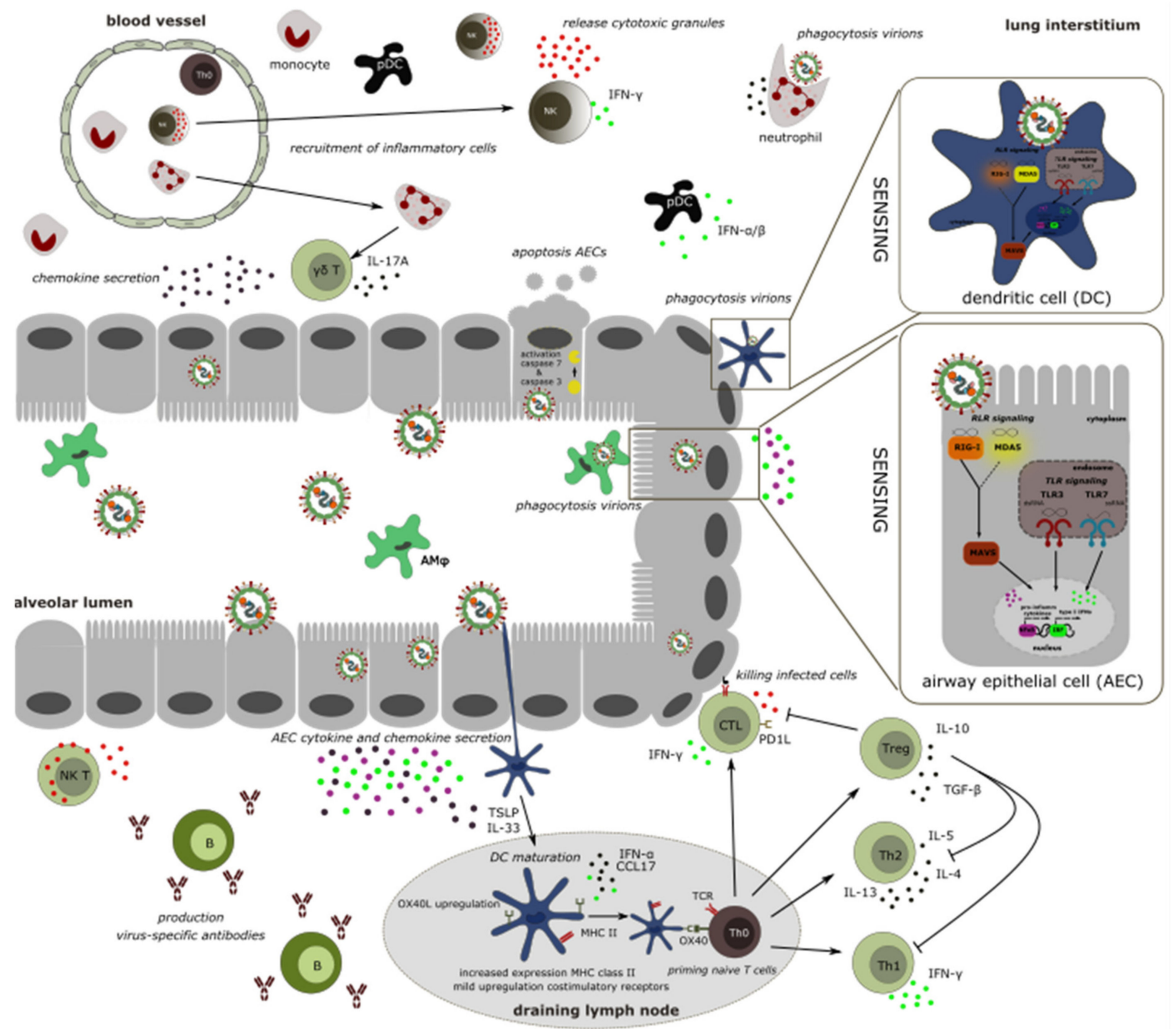

Figure 2. Schematic overview of the interplay between different cell types leading to pulmonary immunopathology upon hMPV infection described in this review. Briefly, dendritic cells (DC), airway epithelial cells (AECs) and alveolar macrophages $(\mathrm{AM} \varphi)$ are the major cell populations that sense hMPV infections. $\mathrm{AM} \varphi$ initiate the primary innate immune response and viral clearance by phagocytosis of hMPV virions. Infected AECs release several pro-inflammatory cytokines, chemokines, and interferons (IFNs) and eventually undergo apoptosis. The signaling pathways induced upon hMPV infection are presented in the zoomed-in box on the right. Activated DCs can stay in the lung and promote local immune responses or they can migrate to the draining lymph nodes and prime naïve T cells (Th0). The activated effector CD4+ and CD8+ T cells expand and migrate back to the lung. Th0 cells can differentiate into several T cell subsets upon hMPV infection including Th1, Th2, regulatory T cells (Tregs), NKT cells, and cytotoxic lymphocytes (CTLs). The last two subsets are able to kill infected cells by the release of cytotoxic granules. Chemokine release by infected AECs recruits several other inflammatory cell types such as NK cells, monocytes, and neutrophils, mediating viral clearance via various killing mechanisms. Another important step in the control of viral infection later in the infection is humoral response through the production of virus-specific antibodies by B cells.

Author Contributions: Concept, literature search, writing and illustrations: M.B.; supervision and editing: X.S. Final approval of the version submitted: MB and XS. All authors have read and agreed to the published version of the manuscript.

Funding: This research was funded by Fonds voor Wetenschappelijk Onderzoek Vlaanderen (FWO) research project 3G043515W and FWO EOS project VIREOS.

Conflicts of Interest: The authors declare no conflict of interest. 


\section{References}

1. Troeger, C.; Forouzanfar, M.; Rao, P.C.; Khalil, I.; Brown, A.; Swartz, S.; Fullman, N.; Mosser, J.; Thompson, R.L.; Reiner, R.C.; et al. Estimates of the global, regional, and national morbidity, mortality, and aetiologies of lower respiratory tract infections in 195 countries: A systematic analysis for the Global Burden of Disease Study 2015. Lancet Infect. Dis. 2017, 17, 1133-1161. [CrossRef]

2. Divarathna, M.V.; Rafeek, R.A.; Noordeen, F. A review on epidemiology and impact of human metapneumovirus infections in children using TIAB search strategy on PubMed and PubMed Central articles. Rev. Med. Virol. 2019, 30. [CrossRef] [PubMed]

3. Hoogen, B.G.V.D.; De Jong, J.C.; Groen, J.; Kuiken, T.; De Groot, R.; Fouchier, R.A.; Osterhaus, A. A newly discovered human pneumovirus isolated from young children with respiratory tract disease. Nat. Med. 2001, 7, 719-724. [CrossRef] [PubMed]

4. Boivin, G.; Abed, Y.; Pelletier, G.; Ruel, L.; Moisan, D.; Côté, S.; Peret, T.C.T.; Erdman, D.D.; Anderson, L.J. Virological Features and Clinical Manifestations Associated with Human Metapneumovirus: A New Paramyxovirus Responsible for Acute Respiratory-Tract Infections in All Age Groups. J. Infect. Dis. 2002, 186, 1330-1334. [CrossRef] [PubMed]

5. Osterhaus, A.; Fouchier, R. Human metapneumovirus in the community. Lancet 2003, 361, 890-891. [CrossRef]

6. Morris, J.A.; Blount, R.E.; Savage, R.E. Recovery of Cytopathogenic Agent from Chimpanzees with Goryza. Exp. Boil. Med. 1956, 92, 544-549. [CrossRef]

7. Rudan, I.; O’Brien, K.L.; Nair, H.; Liu, L.; Theodoratou, E.; Qazi, S.; Lukšić, I.; Walker, C.L.F.; Black, R.E.; Campbell, H. Epidemiology and etiology of childhood pneumonia in 2010: Estimates of incidence, severe morbidity, mortality, underlying risk factors and causative pathogens for 192 countries. J. Glob. Health 2013, 3, 010401 .

8. Ulloa-Gutierrez, R. Metapneumovirus and its place in childhood. Paediatr. Child Health 2003, 8, $613-615$. [CrossRef]

9. Crowe, J.E. Human Metapneumovirus as a Major Cause of Human Respiratory Tract Disease. Pediatr. Infect. Dis. J. 2004, 23, S215-S221. [CrossRef]

10. Hoogen, B.G.V.D.; Osterhaus, D.M.E.; Fouchier, R.A.M. Clinical impact and diagnosis of human metapneumovirus infection. Pediatr. Infect. Dis. J. 2004, 23, S25-S32. [CrossRef]

11. Williams, J.V. Human metapneumovirus: An important cause of respiratory disease in children and adults. Curr. Infect. Dis. Rep. 2005, 7, 204-210. [CrossRef] [PubMed]

12. Edwards, K.M.; Zhu, Y.; Griffin, M.R.; Weinberg, G.A.; Hall, C.B.; Szilagyi, P.G.; Staat, M.A.; Iwane, M.; Prill, M.M.; Williams, J.V.; et al. Burden of human metapneumovirus infection in young children. N. Engl. J. Med. 2013, 368, 633-643. [CrossRef] [PubMed]

13. Schuster, J.E.; Khuri-Bulos, N.; Faouri, S.; Shehabi, A.; Johnson, M.; Wang, L.; Fonnesbeck, C.; Williams, J.V.; Halasa, N. Human Metapneumovirus Infection in Jordanian Children: Epidemiology and Risk Factors for Severe Disease. Pediatr. Infect. Dis. J. 2015, 34, 1335-1341. [CrossRef] [PubMed]

14. Anderson, E.J.; Simões, E.A.; Buttery, J.P.; Dennehy, P.; Domachowske, J.; Jensen, K.; Lieberman, J.M.; Losonsky, G.A.; Yogev, R. Prevalence and Characteristics of Human Metapneumovirus Infection Among Hospitalized Children at High Risk for Severe Lower Respiratory Tract Infection. J. Pediatr. Infect. Dis. Soc. 2012, 1, 212-222. [CrossRef]

15. Hoogen, B.G.V.D.; Van Doornum, G.J.J.; Fockens, J.C.; Cornelissen, J.J.; Beyer, W.E.P.; De Groot, R.; Osterhaus, A.; Fouchier, R.A.M. Prevalence and Clinical Symptoms of Human Metapneumovirus Infection in Hospitalized Patients. J. Infect. Dis. 2003, 188, 1571-1577. [CrossRef]

16. Bosis, S.; Esposito, S.; Niesters, H.; Crovari, P.; Osterhaus, A.; Principi, N. Impact of human metapneumovirus in childhood: Comparison with respiratory syncytial virus and influenza viruses. J. Med. Virol. 2004, 75, 101-104. [CrossRef]

17. Boivin, G.; De Serres, G.; Côté, S.; Gilca, R.; Abed, Y.; Rochette, L.; Bergeron, M.G.; Déry, P. Human metapneumovirus infections in hospitalized children. Emerg. Infect. Dis. 2003, 9, 634. [CrossRef]

18. Peiris, J.M.; Tang, W.-H.; Chan, K.-H.; Khong, P.-L.; Guan, Y.; Lau, Y.-L.; Chiu, S.S. Children with Respiratory Disease Associated with Metapneumovirus in Hong Kong. Emerg. Infect. Dis. 2003, 9, 628-633. [CrossRef]

19. McAdam, A.J.; Hasenbein, M.E.; Feldman, H.A.; Cole, S.E.; Offermann, J.T.; Riley, A.M.; Lieu, T.A. Human Metapneumovirus in Children Tested at a Tertiary-Care Hospital. J. Infect. Dis. 2004, 190, 20-26. [CrossRef] 
20. Leung, J.; Esper, F.; Weibel, C.; Kahn, J.S. Seroepidemiology of Human Metapneumovirus (hMPV) on the Basis of a Novel Enzyme-Linked Immunosorbent Assay Utilizing hMPV Fusion Protein Expressed in Recombinant Vesicular Stomatitis Virus. J. Clin. Microbiol. 2005, 43, 1213-1219. [CrossRef]

21. Lu, G.; Gonzalez, R.; Guo, L.; Wu, C.; Wu, J.; Vernet, G.; Paranhos-Baccalà, G.; Wang, J.; Hung, T. Large-scale seroprevalence analysis of human metapneumovirus and human respiratory syncytial virus infections in Beijing, China. Virol. J. 2011, 8, 62. [CrossRef] [PubMed]

22. Liu, L.; Bastien, N.; Sidaway, F.; Chan, E.; Li, Y. Seroprevalence of human metapneumovirus (hMPV) in the Canadian province of Saskatchewan analyzed by a recombinant nucleocapsid protein-based enzyme-linked immunosorbent assay. J. Med. Virol. 2007, 79, 308-313. [CrossRef] [PubMed]

23. Biacchesi, S.; Skiadopoulos, M.H.; Boivin, G.; Hanson, C.T.; Murphy, B.R.; Collins, P.L.; Buchholz, U.J. Genetic diversity between human metapneumovirus subgroups. Virology 2003, 315, 1-9. [CrossRef]

24. Hoogen, B.G.V.D.; Bestebroer, T.M.; Osterhaus, A.; Fouchier, R. Analysis of the Genomic Sequence of a Human Metapneumovirus. Virology 2002, 295, 119-132. [CrossRef]

25. Williams, J.V.; Harris, P.A.; Tollefson, S.J.; Halburnt-Rush, L.L.; Pingsterhaus, J.M.; Edwards, K.M.; Wright, P.F.; Crowe, J.E. Human metapneumovirus and lower respiratory tract disease in otherwise healthy infants and children. N. Engl. J. Med. 2004, 350, 443-450. [CrossRef]

26. Williams, J.V.; Wang, C.K.; Yang, C.; Tollefson, S.J.; House, F.S.; Heck, J.M.; Chu, M.; Brown, J.B.; Lintao, L.D.; Quinto, J.D.; et al. The role of human metapneumovirus in upper respiratory tract infections in children: A 20-year experience. J. Infect. Dis. 2005, 193, 387-395. [CrossRef]

27. Williams, J.V.; Edwards, K.M.; Weinberg, G.A.; Griffin, M.R.; Hall, C.B.; Zhu, Y.; Szilagyi, P.G.; Wang, C.K.; Yang, C.; Silva, D.; et al. Population-based incidence of human metapneumovirus infection among hospitalized children. J. Infect. Dis. 2010, 201, 1890-1898. [CrossRef]

28. Haas, L.E.M.; Thijsen, S.F.T.; Van Elden, L.J.R.; Heemstra, K.A. Human Metapneumovirus in Adults. Viruses 2013, 5, 87-110. [CrossRef]

29. Li, J.; Ren, L.; Guo, L.; Xiang, Z.; Paranhos-Baccalà, G.; Vernet, G.; Wang, J. Evolutionary Dynamics Analysis of Human Metapneumovirus Subtype A2: Genetic Evidence for Its Dominant Epidemic. PLoS ONE 2012, 7, e34544. [CrossRef]

30. Schildgen, V.; Hoogen, B.V.D.; Fouchier, R.; Tripp, R.A.; Alvarez, R.; Manoha, C.; Williams, J.; Schildgen, O. Human Metapneumovirus: Lessons Learned over the First Decade. Clin. Microbiol. Rev. 2011, 24, 734-754. [CrossRef]

31. Skiadopoulos, M.H.; Biacchesi, S.; Buchholz, U.J.; Riggs, J.M.; Surman, S.R.; Amaro-Carambot, E.; McAuliffe, J.M.; Elkins, W.R.; Claire, M.S.; Collins, P.L.; et al. The Two Major Human Metapneumovirus Genetic Lineages Are Highly Related Antigenically, and the Fusion (F) Protein Is a Major Contributor to This Antigenic Relatedness. J. Virol. 2004, 78, 6927-6937. [CrossRef] [PubMed]

32. Hoogen, B.G.V.D.; Herfst, S.; Sprong, L.; Cane, P.A.; Forleo-Neto, E.; De Swart, R.L.; Osterhaus, A.; Fouchier, R. Antigenic and Genetic Variability of Human Metapneumoviruses. Emerg. Infect. Dis. 2004, 10, 658-666. [CrossRef] [PubMed]

33. MacPhail, M.; Schickli, J.H.; Tang, R.S.; Kaur, J.; Robinson, C.; Fouchier, R.A.M.; Osterhaus, A.; Spaete, R.R.; Haller, A.A. Identification of small-animal and primate models for evaluation of vaccine candidates for human metapneumovirus (hMPV) and implications for hMPV vaccine design. J. Gen. Virol. 2004, 85, 1655-1663. [CrossRef] [PubMed]

34. Hoogen, B.V.D.; Herfst, S.; De Graaf, M.; Sprong, L.; Van Lavieren, R.; Van Amerongen, G.; Yüksel, S.; Fouchier, R.A.M.; Osterhaus, A.; De Swart, R.L. Experimental infection of macaques with human metapneumovirus induces transient protective immunity. J. Gen. Virol. 2007, 88, 1251-1259. [CrossRef] [PubMed]

35. Pelletier, G.; Déry, P.; Abed, Y.; Boivin, G. Respiratory Tract Reinfections by the New Human Metapneumovirus in an Immunocompromised Child. Emerg. Infect. Dis. 2002, 8, 976-978. [CrossRef] [PubMed]

36. Yang, C.-F.; Wang, C.K.; Tollefson, S.J.; Piyaratna, R.; Lintao, L.D.; Chu, M.; Liem, A.; Mark, M.; Spaete, R.R.; Crowe, J.E.; et al. Genetic diversity and evolution of human metapneumovirus fusion protein over twenty years. Virol. J. 2009, 6, 138. [CrossRef]

37. Peret, T.C.T.; Abed, Y.; Anderson, L.J.; Erdman, D.D.; Boivin, G. Sequence polymorphism of the predicted human metapneumovirus G glycoprotein. J. Gen. Virol. 2004, 85, 679-686. [CrossRef] 
38. Tang, R.S.; Mahmood, K.; MacPhail, M.; Guzzetta, J.M.; Haller, A.A.; Liu, H.; Kaur, J.; Lawlor, H.A.; Stillman, E.A.; Schickli, J.H.; et al. A host-range restricted parainfluenza virus type 3 (PIV3) expressing the human metapneumovirus (hMPV) fusion protein elicits protective immunity in African green monkeys. Vaccine 2005, 23, 1657-1667. [CrossRef]

39. Skiadopoulos, M.H.; Biacchesi, S.; Buchholz, U.J.; Amaro-Carambot, E.; Surman, S.R.; Collins, P.L.; Murphy, B.R. Individual contributions of the human metapneumovirus F, G, and SH surface glycoproteins to the induction of neutralizing antibodies and protective immunity. Virology 2006, 345, 492-501. [CrossRef]

40. Ruigrok, R.W.H.; Crepin, T.; Kolakofsky, D. Nucleoproteins and nucleocapsids of negative-strand RNA viruses. Curr. Opin. Microbiol. 2011, 14, 504-510. [CrossRef]

41. Rogers, M.; Williams, J.V. Quis Custodiet Ipsos Custodes? Regulation of Cell-Mediated Immune Responses Following Viral Lung Infections. Annu. Rev. Virol. 2018, 5, 363-383. [CrossRef] [PubMed]

42. Englund, J.A.; Boeckh, M.; Kuypers, J.; Nichols, W.G.; Hackman, R.C.; Morrow, R.A.; Fredricks, D.N.; Corey, L. Brief communication: Fatal human metapneumovirus infection in stem-cell transplant recipients. Ann. Intern. Med. 2006, 144, 344-349. [CrossRef] [PubMed]

43. Debiaggi, M.; Canducci, F.; Sampaolo, M.; Marinozzi, M.C.; Parea, M.; Terulla, C.; Colombo, A.; Alessandrino, E.P.; Bragotti, L.Z.; Arghittu, M.; et al. Persistent Symptomless Human Metapneumovirus Infection in Hematopoietic Stem Cell Transplant Recipients. J. Infect. Dis. 2006, 194, 474-478. [CrossRef] [PubMed]

44. Soto, J.A.; Gálvez, N.M.S.; Benavente, F.M.; Pizarro-Ortega, M.S.; Lay, M.K.; Riedel, C.; Bueno, S.M.; Gonzalez, P.A.; Kalergis, A.M. Human Metapneumovirus: Mechanisms and Molecular Targets Used by the Virus to Avoid the Immune System. Front. Immunol. 2018, 9. [CrossRef] [PubMed]

45. Falsey, A.R.; Erdman, D.; Anderson, L.J.; Walsh, E.E. Human Metapneumovirus Infections in Young and Elderly Adults. J. Infect. Dis. 2003, 187, 785-790. [CrossRef]

46. Pavlin, J.A.; Hickey, A.C.; Ulbrandt, N.; Chan, Y.-P.; Endy, T.P.; Boukhvalova, M.S.; Chunsuttiwat, S.; Nisalak, A.; Libraty, D.H.; Green, S.; et al. Human metapneumovirus reinfection among children in Thailand determined by ELISA using purified soluble fusion protein. J. Infect. Dis. 2008, 198, 836-842. [CrossRef]

47. Vargas, S.O.; Kozakewich, H.P.; Perez-Atayde, A.R.; McAdam, A.J. Pathology of Human Metapneumovirus Infection: Insights into the Pathogenesis of a Newly Identified Respiratory Virus. Pediatr. Dev. Pathol. 2004, 7, 478-486. [CrossRef]

48. Kolli, D.; Gupta, M.R.; Sbrana, E.; Velayutham, T.S.; Chao, H.; Casola, A.; Garofalo, R.P. Alveolar Macrophages Contribute to the Pathogenesis of Human Metapneumovirus Infection while Protecting against Respiratory Syncytial Virus Infection. Am. J. Respir. Cell Mol. Boil. 2014, 51, 502-515. [CrossRef]

49. Tan, M.C.; Battini, L.; Tuyama, A.C.; Macip, S.; Melendi, G.A.; Horga, M.-A.; Gusella, G.L. Characterization of human metapneumovirus infection of myeloid dendritic cells. Virology 2007, 357, 1-9. [CrossRef]

50. Homaira, N.; Luby, S.; Petri, W.A.; Vainionpää, R.; Rahman, M.; Hossain, K.; Snider, C.B.; Rahman, M.; Alamgir, A.S.M.; Zesmin, F.; et al. Incidence of Respiratory Virus-Associated Pneumonia in Urban Poor Young Children of Dhaka, Bangladesh, 2009-2011. PLoS ONE 2012, 7, e32056. [CrossRef]

51. Jain, S.; Self, W.H.; Wunderink, R.G.; Fakhran, S.; Balk, R.; Bramley, A.M.; Reed, C.; Grijalva, C.G.; Anderson, E.J.; Courtney, D.M.; et al. Community-acquired pneumonia requiring hospitalization among U.S. adults. N. Engl. J. Med. 2015, 373, 415-427. [CrossRef] [PubMed]

52. Chang, Y.-F.; Tsao, K.-C.; Liu, Y.; Chen, Y.-C.; Yu, P.-C.; Huang, Y.-C.; Chou, C. Diagnosis of human metapneumovirus in patients hospitalized with acute lower respiratory tract infection using a metal-enhanced fluorescence technique. J. Virol. Methods 2015, 213, 151-156. [CrossRef] [PubMed]

53. Kuiken, T.; Hoogen, B.G.V.D.; Van Riel, D.; Laman, J.D.; Van Amerongen, G.; Sprong, L.; Fouchier, R.A.; Osterhaus, A. Experimental Human Metapneumovirus Infection of Cynomolgus Macaques (Macaca fascicularis) Results in Virus Replication in Ciliated Epithelial Cells and Pneumocytes with Associated Lesions throughout the Respiratory Tract. Am. J. Pathol. 2004, 164, 1893-1900. [CrossRef]

54. Hamelin, M.-È; Prince, G.A.; Gomez, A.M.; Kinkead, R.; Boivin, G. Human Metapneumovirus Infection Induces Long?Term Pulmonary Inflammation Associated with Airway Obstruction and Hyperresponsiveness in Mice. J. Infect. Dis. 2006, 193, 1634-1642. [CrossRef]

55. Williams, J.V.; Tollefson, S.J.; Johnson, J.E.; Crowe, J.E. The Cotton Rat (Sigmodon hispidus) Is a Permissive Small Animal Model of Human Metapneumovirus Infection, Pathogenesis, and Protective Immunity. J. Virol. 2005, 79, 10944-10951. [CrossRef] [PubMed] 
56. Takeuchi, O.; Akira, S. Pattern Recognition Receptors and Inflammation. Cell 2010, 140, 805-820. [CrossRef]

57. Liao, S.; Bao, X.; Liu, T.; Lai, S.; Li, K.; Garofalo, R.P.; Casola, A. Role of retinoic acid inducible gene-I in human metapneumovirus-induced cellular signalling. J. Gen. Virol. 2008, 89, 1978-1986. [CrossRef]

58. Bao, X.; Liu, T.; Spetch, L.; Kolli, D.; Garofalo, R.; Casola, A. Airway epithelial cell response to human metapneumovirus infection. Virology 2007, 368, 91-101. [CrossRef]

59. Bao, X.; Sinha, M.; Liu, T.; Hong, C.; Luxon, B.; Garofalo, R.; Casola, A. Identification of human metapneumovirus-induced gene networks in airway epithelial cells by microarray analysis. Virology 2008, 374, 114-127. [CrossRef]

60. Kawai, T.; Takahashi, K.; Sato, S.; Coban, C.; Kumar, H.; Kato, H.; Ishii, K.J.; Takeuchi, O.; Akira, S. IPS-1, an adaptor triggering RIG-I- and Mda5-mediated type I interferon induction. Nat. Immunol. 2005, 6, 981-988. [CrossRef]

61. Seth, R.B.; Sun, L.; Ea, C.-K.; Chen, Z.J. Identification and Characterization of MAVS, a Mitochondrial Antiviral Signaling Protein that Activates NF-kB and IRF3. Cell 2005, 122, 669-682. [CrossRef] [PubMed]

62. Schneider, W.M.; Chevillotte, M.D.; Rice, C.M. Interferon-stimulated genes: A complex web of host defenses. Annu. Rev. Immunol. 2014, 32, 513-545. [CrossRef] [PubMed]

63. Baños-Lara, M.D.R.; Piao, B.; Guerrero-Plata, A. Differential Mucin Expression by Respiratory Syncytial Virus and Human Metapneumovirus Infection in Human Epithelial Cells. Mediat. Inflamm. 2015, 2015, 1-7. [CrossRef] [PubMed]

64. Loevenich, S.; Malmo, J.; Liberg, A.M.; Sherstova, T.; Li, Y.; Rian, K.; Johnsen, I.B.; Anthonsen, M.W. Cell-Type-Specific Transcription of Innate Immune Regulators in response to HMPV Infection. Mediat. Inflamm. 2019, 2019, 4964239-13. [CrossRef] [PubMed]

65. Schoggins, J.W.; MacDuff, N.A.; Imanaka, N.; Gainey, M.D.; Shrestha, B.; Eitson, J.L.; Mar, K.B.; Richardson, R.B.; Ratushny, A.V.; Litvak, V.; et al. Pan-viral specificity of IFN-induced genes reveals new roles for cGAS in innate immunity. Nature 2013, 505, 691-695. [CrossRef] [PubMed]

66. McMichael, T.M.; Zhang, Y.; Kenney, A.; Zhang, L.; Zani, A.; Lu, M.; Chemudupati, M.; Li, J.; Yount, J.S. IFITM3 Restricts Human Metapneumovirus Infection. J. Infect. Dis. 2018. [CrossRef]

67. Weber, F.; Haller, O. Viral suppression of the interferon system. Biochimie 2007, 89, 836-842. [CrossRef]

68. Dinwiddie, D.L.; Harrod, K. Human Metapneumovirus Inhibits IFN- $\alpha$ Signaling through Inhibition of STAT1 Phosphorylation. Am. J. Respir. Cell Mol. Boil. 2008, 38, 661-670. [CrossRef]

69. Ren, J.; Kolli, D.; Liu, T.; Xu, R.; Garofalo, R.P.; Casola, A.; Bao, X. Human Metapneumovirus Inhibits IFN- $\beta$ Signaling by Downregulating Jak1 and Tyk2 Cellular Levels. PLoS ONE 2011, 6, e24496. [CrossRef]

70. Bao, X.; Liu, T.; Shan, Y.; Li, K.; Garofalo, R.P.; Casola, A. Human Metapneumovirus Glycoprotein G Inhibits Innate Immune Responses. PLoS Pathog. 2008, 4, e1000077. [CrossRef]

71. Uche, I.K.; Guerrero-Plata, A. Interferon-Mediated Response to Human Metapneumovirus Infection. Viruses 2018, 10, 505. [CrossRef] [PubMed]

72. Baggiolini, M.; Dewald, B.; Moser, B. Human Chemokines: An Update. Annu. Rev. Immunol. 1997, 15, 675-705. [CrossRef] [PubMed]

73. Deshmane, S.L.; Kremlev, S.; Amini, S.; Sawaya, B.E. Monocyte Chemoattractant Protein-1 (MCP-1): An Overview. J. Interf. Cytokine Res. 2009, 29, 313-326. [CrossRef] [PubMed]

74. Futosi, K.; Fodor, S.; Mócsai, A. Neutrophil cell surface receptors and their intracellular signal transduction pathways. Int. Immunopharmacol. 2013, 17, 1185-1197. [CrossRef] [PubMed]

75. Hamelin, M.-E.; Yim, K.; Kuhn, K.H.; Cragin, R.P.; Boukhvalova, M.; Blanco, J.C.G.; Prince, G.A.; Boivin, G. Pathogenesis of Human Metapneumovirus Lung Infection in BALB/c Mice and Cotton Rats. J. Virol. 2005, 79, 8894-8903. [CrossRef]

76. Lay, M.K.; Céspedes, P.F.; Palavecino, C.E.; León, M.A.; Díaz, R.A.; Salazar, F.J.; Méndez, G.P.; Bueno, S.M.; Kalergis, A.M. Human metapneumovirus infection activates the TSLP pathway that drives excessive pulmonary inflammation and viral replication in mice. Eur. J. Immunol. 2015, 45, 1680-1695. [CrossRef]

77. Inngjerdingen, M.; Damaj, B.; Maghazachi, A.A.; Maghazachi, A. Human NK cells express CC chemokine receptors 4 and 8 and respond to thymus and activation-regulated chemokine, macrophage-derived chemokine, and I-309. J. Immunol. 2000, 164, 4048-4054. [CrossRef]

78. Liu, Y.-J. Thymic stromal lymphopoietin: Master switch for allergic inflammation. J. Exp. Med. 2006, 203, 269-273. [CrossRef] 
79. Li, Y.; Lund, C.; Nervik, I.; Loevenich, S.; Døllner, H.; Anthonsen, M.W.; Johnsen, I.B. Characterization of signaling pathways regulating the expression of pro-inflammatory long form thymic stromal lymphopoietin upon human metapneumovirus infection. Sci. Rep. 2018, 8, 883. [CrossRef]

80. De Graaf, M.; Herfst, S.; Aarbiou, J.; Burgers, P.C.; Zaaraoui-Boutahar, F.; Bijl, M.; Van Ijcken, W.F.J.; Schrauwen, E.J.A.; Osterhaus, A.; Luider, T.M.; et al. Small Hydrophobic Protein of Human Metapneumovirus Does Not Affect Virus Replication and Host Gene Expression In Vitro. PLoS ONE 2013, 8, e58572. [CrossRef]

81. De Lamballerie, C.N.; Pizzorno, A.; Dubois, J.; Julien, T.; Padey, B.; Bouveret, M.; Traversier, A.; Legras-Lachuer, C.; Lina, B.; Boivin, G.; et al. Characterization of cellular transcriptomic signatures induced by different respiratory viruses in human reconstituted airway epithelia. Sci. Rep. 2019, 9, 11493. [CrossRef] [PubMed]

82. Zhao, Y.; Chahar, H.S.; Komaravelli, N.; Dossumekova, A.; Casola, A. Human metapneumovirus infection of airway epithelial cells is associated with changes in core metabolic pathways. Virology 2019, 531, 183-191. [CrossRef]

83. Sanchez, E.L.; Lagunoff, M. Viral activation of cellular metabolism. Virology 2015, 479, 609-618. [CrossRef] [PubMed]

84. Hosakote, Y.M.; Jantzi, P.D.; Esham, D.L.; Spratt, H.; Kurosky, A.; Casola, A.; Garofalo, R.P. Viral-mediated Inhibition of Antioxidant Enzymes Contributes to the Pathogenesis of Severe Respiratory Syncytial Virus Bronchiolitis. Am. J. Respir. Crit. Care Med. 2011, 183, 1550-1560. [CrossRef] [PubMed]

85. Shelton, P.; Jaiswal, A.K. The transcription factor NF-E2-related Factor 2 (Nrf2): A protooncogene? FASEB J. 2012, 27, 414-423. [CrossRef] [PubMed]

86. Ivanciuc, T.; Sbrana, E.; Casola, A.; Garofalo, R.P. Protective Role of Nuclear Factor Erythroid 2-Related Factor 2 Against Respiratory Syncytial Virus and Human Metapneumovirus Infections. Front. Immunol. 2018, 9. [CrossRef]

87. Hay, S.; Kannourakis, G. A time to kill: Viral manipulation of the cell death program. J. Gen. Virol. 2002, 83, 1547-1564. [CrossRef]

88. Hilleman, M.R. Strategies and mechanisms for host and pathogen survival in acute and persistent viral infections. Proc. Natl. Acad. Sci. USA 2004, 101, 14560-14566. [CrossRef]

89. Marsico, S.; Caccuri, F.; Mazzuca, P.; Apostoli, P.; Roversi, S.; Lorenzin, G.; Zani, A.; Fiorentini, S.; Giagulli, C.; Caruso, A. Human lung epithelial cells support human metapneumovirus persistence by overcoming apoptosis. Pathog. Dis. 2018, 76. [CrossRef]

90. Young, L.S.; Dawson, C.W.; Eliopoulos, A.G. Viruses and apoptosis. Br. Med. Bull. 1997, 53, 509-521. [CrossRef]

91. Alvarez, R.; Harrod, K.; Shieh, W.-J.; Zaki, S.; Tripp, R.A. Human Metapneumovirus Persists in BALB/c Mice despite the Presence of Neutralizing Antibodies. J. Virol. 2004, 78, 14003-14011. [CrossRef] [PubMed]

92. Alvarez, R.; Tripp, R.A. The Immune Response to Human Metapneumovirus Is Associated with Aberrant Immunity and Impaired Virus Clearance in BALB/c Mice. J. Virol. 2005, 79, 5971-5978. [CrossRef] [PubMed]

93. Liu, Y.; Haas, D.L.; Poore, S.; Isakovic, S.; Gahan, M.E.; Mahalingam, S.; Fu, Z.F.; Tripp, R.A. Human Metapneumovirus Establishes Persistent Infection in the Lungs of Mice and Is Reactivated by Glucocorticoid Treatment. J. Virol. 2009, 83, 6837-6848. [CrossRef] [PubMed]

94. Abed, Y.; Boivin, G. Persistent Human Metapneumovirus Infection in Immunocompromised Child. Emerg. Infect. Dis. 2008, 14, 854-856. [CrossRef]

95. Newton, A.H.; Cardani, A.; Braciale, T.J. The host immune response in respiratory virus infection: Balancing virus clearance and immunopathology. Semin. Immunopathol. 2016, 38, 471-482. [CrossRef]

96. Pribul, P.K.; Harker, J.A.; Wang, B.; Wang, H.; Tregoning, J.; Schwarze, J.; Openshaw, P.J. Alveolar Macrophages Are a Major Determinant of Early Responses to Viral Lung Infection but Do Not Influence Subsequent Disease Development. J. Virol. 2008, 82, 4441-4448. [CrossRef]

97. Benoit, A.; Huang, Y.; Proctor, J.; Rowden, G.; Anderson, R. Effects of alveolar macrophage depletion on liposomal vaccine protection against respiratory syncytial virus (RSV). Clin. Exp. Immunol. 2006, 145, 147-154. [CrossRef]

98. Li, Y.; Østerhus, S.; Johnsen, I.B. Human Metapneumovirus Infection Inhibits Cathelicidin Antimicrobial Peptide Expression in Human Macrophages. Front. Immunol. 2018, 9. [CrossRef]

99. Cheemarla, N.; Baños-Lara, M.D.R.; Naidu, S.; Guerrero-Plata, A. Neutrophils regulate the lung inflammatory response via $\gamma \delta \mathrm{T}$ cell infiltration in an experimental mouse model of human metapneumovirus infection. J. Leukoc. Boil. 2017, 101, 1383-1392. [CrossRef] 
100. Wen, S.C.; Tollefson, S.J.; Johnson, M.; Gilchuk, P.; Boyd, K.L.; Shepherd, B.; Joyce, S.; Williams, J.V. Acute Clearance of Human Metapneumovirus Occurs Independently of Natural Killer Cells. J. Virol. 2014, 88, 10963-10969. [CrossRef]

101. Kolli, D.; Bataki, E.L.; Spetch, L.; Guerrero-Plata, A.; Jewell, A.M.; Piedra, P.A.; Milligan, G.N.; Garofalo, R.P.; Casola, A. T Lymphocytes Contribute to Antiviral Immunity and Pathogenesis in Experimental Human Metapneumovirus Infection. J. Virol. 2008, 82, 8560-8569. [CrossRef] [PubMed]

102. Rogers, M.; Lamens, K.; Shafagati, N.; Johnson, M.; Oury, T.D.; Joyce, S.; Williams, J.V. CD4+ Regulatory T Cells Exert Differential Functions during Early and Late Stages of the Immune Response to Respiratory Viruses. J. Immunol. 2018, 201, 1253-1266. [CrossRef] [PubMed]

103. Melendi, G.A.; Zavala, F.; Buchholz, U.J.; Boivin, G.; Collins, P.L.; Kleeberger, S.R.; Polack, F.P. Mapping and Characterization of the Primary and Anamnestic H-2d-Restricted Cytotoxic T-Lymphocyte Response in Mice against Human Metapneumovirus. J. Virol. 2007, 81, 11461-11467. [CrossRef]

104. Culshaw, S.; Millington, O.R.; Brewer, J.M.; McInnes, I. Murine neutrophils present Class II restricted antigen. Immunol. Lett. 2008, 118, 49-54. [CrossRef] [PubMed]

105. Pulendran, B.; Maddur, M.S. Innate Immune Sensing and Response to Influenza. Curr. Top. Microbiol. Immunol. 2014, 386, 23-71. [CrossRef]

106. Cheemarla, N.; Guerrero-Plata, A. Immune Response to Human Metapneumovirus Infection: What We Have Learned from the Mouse Model. Pathogens 2015, 4, 682-696. [CrossRef]

107. Cavallaro, E.; Liang, K.; Lawrence, M.D.; Forsyth, K.D.; Dixon, D.-L. Neutrophil infiltration and activation in bronchiolitic airways are independent of viral etiology. Pediatr. Pulmonol. 2016, 52, 238-246. [CrossRef]

108. Daley, J.M.; Thomay, A.A.; Connolly, M.D.; Reichner, J.; Albina, J. Use of Ly6G-specific monoclonal antibody to deplete neutrophils in mice. J. Leukoc. Boil. 2007, 83, 64-70. [CrossRef]

109. Cortjens, B.; Ingelse, S.A.; Calis, J.C.J.; Vlaar, A.P.; Koenderman, L.; Bem, R.A.; Van Woensel, J.B. Neutrophil subset responses in infants with severe viral respiratory infection. Clin. Immunol. 2017, 176, 100-106. [CrossRef]

110. Pillay, J.; Kamp, V.M.; Van Hoffen, E.; Visser, T.; Tak, T.; Lammers, J.-W.; Ulfman, L.H.; Leenen, L.P.; Pickkers, P.; Koenderman, L. A subset of neutrophils in human systemic inflammation inhibits $\mathrm{T}$ cell responses through Mac-1. J. Clin. Investig. 2011, 122, 327-336. [CrossRef]

111. Zilio, S.; Serafini, P. Neutrophils and Granulocytic MDSC: The Janus God of Cancer Immunotherapy. Vaccines 2016, 4, 31. [CrossRef] [PubMed]

112. Cheemarla, N.; Guerrero-Plata, A. Human Metapneumovirus Attachment Protein Contributes to Neutrophil Recruitment into the Airways of Infected Mice. Viruses 2017, 9, 310. [CrossRef] [PubMed]

113. Baños-Lara, M.D.R.; Harvey, L.; Mendoza, A.; Simms, D.; Chouljenko, V.N.; Wakamatsu, N.; Kousoulas, K.G.; Guerrero-Plata, A. Impact and Regulation of Lambda Interferon Response in Human Metapneumovirus Infection. J. Virol. 2014, 89, 730-742. [CrossRef]

114. Guerrero-Plata, A. Dendritic Cells in Human Pneumovirus and Metapneumovirus Infections. Viruses 2013, 5, 1553-1570. [CrossRef] [PubMed]

115. Neyt, K.; Lambrecht, B.N. The role of lung dendritic cell subsets in immunity to respiratory viruses. Immunol. Rev. 2013, 255, 57-67. [CrossRef]

116. Guerrero-Plata, A.; Kolli, D.; Hong, C.; Casola, A.; Garofalo, R.P. Subversion of pulmonary dendritic cell function by paramyxovirus infections. J. Immunol. 2009, 182, 3072-3083. [CrossRef]

117. Guerrero-Plata, A.; Casola, A.; Suárez, G.; Yu, X.; Spetch, L.; Peeples, M.E.; Garofalo, R.P. Differential Response of Dendritic Cells to Human Metapneumovirus and Respiratory Syncytial Virus. Am. J. Respir. Cell Mol. Boil. 2006, 34, 320-329. [CrossRef]

118. Bao, X.; Kolli, D.; Esham, D.; Velayutham, T.S.; Casola, A. Human Metapneumovirus Small Hydrophobic Protein Inhibits Interferon Induction in Plasmacytoid Dendritic Cells. Viruses 2018, 10, 278. [CrossRef]

119. Goutagny, N.; Jiang, Z.; Tian, J.; Parroche, P.; Schickli, J.; Monks, B.G.; Ulbrandt, N.; Ji, H.; Kiener, P.A.; Coyle, A.J.; et al. Cell type-specific recognition of human metapneumoviruses (HMPVs) by retinoic acid-inducible gene I (RIG-I) and TLR7 and viral interference of RIG-I ligand recognition by HMPV-B1 phosphoprotein. J. Immunol. 2009, 184, 1168-1179. [CrossRef]

120. Smyth, L.A.; Boardman, D.; Tung, S.L.; Lechler, R.; Lombardi, G. MicroRNAs affect dendritic cell function and phenotype. Immunology 2015, 144, 197-205. [CrossRef] 
121. Banos-Lara, M.; Zabaleta, J.; Garai, J.; Baddoo, M.; Guerrero-Plata, A. Comparative analysis of miRNA profile in human dendritic cells infected with respiratory syncytial virus and human metapneumovirus. BMC Res. Notes 2018, 11, 432. [CrossRef] [PubMed]

122. Le Nouën, C.; Hillyer, P.; Munir, S.; Winter, C.C.; Mccarty, T.; Bukreyev, A.; Collins, P.L.; Rabin, R.L.; Buchholz, U.J. Effects of Human Respiratory Syncytial Virus, Metapneumovirus, Parainfluenza Virus 3 and Influenza Virus on CD4+ T Cell Activation by Dendritic Cells. PLoS ONE 2010, 5, e15017. [CrossRef] [PubMed]

123. Céspedes, P.F.; Gonzalez, P.A.; Kalergis, A.M. Human metapneumovirus keeps dendritic cells from priming antigen-specific naive T cells. Immunology 2013, 139, 366-376. [CrossRef] [PubMed]

124. Hoogen, B.V.D.; Van Boheemen, S.; De Rijck, J.; Van Nieuwkoop, S.; Smith, D.J.; Laksono, B.; Gultyaev, A.; Osterhaus, A.D.M.E.; Fouchier, R.A.M. Excessive production and extreme editing of human metapneumovirus defective interfering RNA is associated with type I IFN induction. J. Gen. Virol. 2014, 95, 1625-1633. [CrossRef] [PubMed]

125. Huang, A.S. Defective Interfering Viruses. Annu. Rev. Microbiol. 1973, 27, 101-118. [CrossRef] [PubMed]

126. Biacchesi, S.; Skiadopoulos, M.H.; Yang, L.; Lamirande, E.W.; Tran, K.C.; Murphy, B.R.; Collins, P.L.; Buchholz, U.J. Recombinant Human Metapneumovirus Lacking the Small Hydrophobic SH and/or Attachment G Glycoprotein: Deletion of G Yields a Promising Vaccine Candidate. J. Virol. 2004, 78, 12877-12887. [CrossRef]

127. Biacchesi, S.; Skiadopoulos, M.H.; Tran, K.C.; Murphy, B.R.; Collins, P.L.; Buchholz, U.J. Recovery of human metapneumovirus from cDNA: Optimization of growth in vitro and expression of additional genes. Virology 2004, 321, 247-259. [CrossRef]

128. Le, V.B.; Dubois, J.; Couture, C.; Cavanagh, M.H.; Uyar, O.; Pizzorno, A.; Rosa-Calatrava, M.; Hamelin, M.E.; Boivin, G. Human metapneumovirus activates NOD-like receptor protein 3 inflammasome via its smallhydrophobic protein which plays adetrimental role during infection in mice. PLoS Pathog. 2019, 15, e1007689. [CrossRef]

129. Kolli, D.; Bao, X.; Liu, T.; Hong, C.; Wang, T.; Garofalo, R.P.; Casola, A. Human metapneumovirus glycoprotein $\mathrm{G}$ inhibits TLR4-dependent signaling in monocyte-derived dendritic cells. J. Immunol. 2011, 187, 47-54. [CrossRef]

130. Preston, F.M.; Straub, C.P.; Ramirez, R.; Mahalingam, S.; Spann, K. siRNA against the G gene of human metapneumovirus. Virol. J. 2012, 9, 105. [CrossRef]

131. Dossumbekova, A.; Kolli, D.; Esham, D.L.; Liu, T.; Casola, A. Human Metapneumovirus Small Hydrophobic Protein Inhibits Interferon Induction in Plasmacytoid Dendritic Cells via TLR7 Signaling Pathway. J. Allergy Clin. Immunol. 2017, 139, AB16. [CrossRef]

132. Hastings, A.K.; Amato, K.R.; Wen, S.C.; Peterson, L.S.; Williams, J.V. Human metapneumovirus small hydrophobic $(\mathrm{SH})$ protein downregulates type I IFN pathway signaling by affecting STAT1 expression and phosphorylation. Virology 2016, 494, 248-256. [CrossRef] [PubMed]

133. Biacchesi, S.; Pham, Q.N.; Skiadopoulos, M.H.; Murphy, B.R.; Collins, P.L.; Buchholz, U.J. Infection of Nonhuman Primates with Recombinant Human Metapneumovirus Lacking the SH, G, or M2-2 Protein Categorizes Each as a Nonessential Accessory Protein and Identifies Vaccine Candidates. J. Virol. 2005, 79, 12608-12613. [CrossRef]

134. Ren, J.; Liu, G.; Go, J.; Kolli, D.; Zhang, G.; Bao, X. Human Metapneumovirus M2-2 Protein Inhibits Innate Immune Response in Monocyte-Derived Dendritic Cells. PLoS ONE 2014, 9, e91865. [CrossRef] [PubMed]

135. Kitagawa, Y.; Sakai, M.; Funayama, M.; Itoh, M.; Gotoh, B. Human Metapneumovirus M2-2 Protein Acts as a Negative Regulator of Alpha Interferon Production by Plasmacytoid Dendritic Cells. J. Virol. 2017, 91, e00579-17. [CrossRef] [PubMed]

136. Ren, Y.; Li, C.; Feng, L.; Pan, W.; Li, L.; Wang, Q.; Li, J.; Li, N.; Han, L.; Zheng, X.; et al. Proton Channel Activity of Influenza A Virus Matrix Protein 2 Contributes to Autophagy Arrest. J. Virol. 2015, 90, 591-598. [CrossRef]

137. Ren, Y.; Choi, E.; Zhang, K.; Chen, Y.; Ye, S.; Deng, X.; Zhang, K.; Bao, X. Detection of Nuclear Protein Profile Changes by Human Metapneumovirus M2-2 Protein Using Quantitative Differential Proteomics. Vaccines 2017, 5, 45. [CrossRef]

138. Choi, E.; Wu, W.; Chen, Y.; Yan, W.; Li, L.; Choudhury, A.; Bao, X. The role of M2-2 PDZ-binding motifs in pulmonary innate immune responses to human metapneumovirus. J. Med. Virol. 2020, 2. [CrossRef] 
139. Obeidy, P.; Sharland, A.F. NKG2D and its ligands. Int. J. Biochem. Cell Boil. 2009, 41, 2364-2367. [CrossRef]

140. Stern-Ginossar, N.; Mandelboim, O. An integrated view of the regulation of NKG2D ligands. Immunology 2009, 128, 1-6. [CrossRef]

141. Uzhachenko, R.V.; Shanker, A. CD8+ T Lymphocyte and NK Cell Network: Circuitry in the Cytotoxic Domain of Immunity. Front. Immunol. 2019, 10, 1906. [CrossRef] [PubMed]

142. Huck, B.; Neumann-Haefelin, D.; Schmitt-Graeff, A.; Weckmann, M.; Mattes, J.; Ehl, S.; Falcone, V. Human metapneumovirus induces more severe disease and stronger innate immune response in BALB/c mice as compared with respiratory syncytial virus. Respir. Res. 2007, 8, 6. [CrossRef] [PubMed]

143. Gaya, M.; Barral, P.; Burbage, M.; Aggarwal, S.; Montaner, B.; Navia, A.W.; Aid, M.; Tsui, C.; Maldonado, P.; Nair, U.; et al. Initiation of Antiviral B Cell Immunity Relies on Innate Signals from Spatially Positioned NKT Cells. Cell 2018, 172, 517-533. [CrossRef] [PubMed]

144. Van Kaer, L. Regulation of Immune Responses by CD1d-Restricted Natural Killer T Cells. Immunol. Res. 2004, 30, 139-154. [CrossRef]

145. Diab, M.; Glasner, A.; Isaacson, B.; Bar-On, Y.; Drori, Y.; Yamin, R.; Duev-Cohen, A.; Danziger, O.; Zamostiano, R.; Mandelboim, M.; et al. NK-cell receptors NKp46 and NCR1 control human metapneumovirus infection. Eur. J. Immunol. 2017, 47, 692-703. [CrossRef] [PubMed]

146. Ivanov, S.; Paget, C.; Trottein, F. Role of Non-conventional T Lymphocytes in Respiratory Infections: The Case of the Pneumococcus. PLoS Pathog. 2014, 10, e1004300. [CrossRef] [PubMed]

147. Herd, K.A.; Nissen, M.; Hopkins, P.M.; Sloots, T.P.; Tindle, R.W. Major Histocompatibility Complex Class I Cytotoxic T Lymphocyte Immunity to Human Metapneumovirus (hMPV) in Individuals with Previous hMPV Infection and Respiratory Disease. J. Infect. Dis. 2008, 197, 584-592. [CrossRef]

148. Laham, F.R.; Israele, V.; Casellas, J.M.; Garcia, A.M.; Prugent, C.M.L.; Hoffman, S.J.; Hauer, D.; Thumar, B.; Name, M.I.; Pascual, A.; et al. Differential Production of Inflammatory Cytokines in Primary Infection with Human Metapneumovirus and with Other Common Respiratory Viruses of Infancy. J. Infect. Dis. 2004, 189, 2047-2056. [CrossRef]

149. Douville, R.N.; Bastien, N.; Li, Y.; Pochard, P.; Simons, F.E.R.; HayGlass, K.T. Human Metapneumovirus Elicits Weak IFN- $\gamma$ Memory Responses Compared with Respiratory Syncytial Virus. J. Immunol. 2006, 176, 5848-5855. [CrossRef]

150. Sakaguchi, S.; Wing, K.; Onishi, Y.; Prieto-Martin, P.; Yamaguchi, T. Regulatory T cells: How do they suppress immune responses? Int. Immunol. 2009, 21, 1105-1111. [CrossRef]

151. Liu, Y.; Qin, T.; Zhao, X.; Dong, S.; Zhu, J.; Peng, D.; Zhong, J.; Li, T.; Chen, X. Skewed balance of regulatory T cell and inflammatory T cell in IL-17 defect with human metapneumovirus infection. Cell. Immunol. 2018, 331, 161-167. [CrossRef] [PubMed]

152. Tzannou, I.; Nicholas, S.K.; Lulla, P.; Aguayo-Hiraldo, P.I.; Misra, A.; Martinez, C.A.; Machado, A.; Orange, J.S.; Piedra, P.A.; Vera, J.F.; et al. Immunologic Profiling of Human Metapneumovirus for the Development of Targeted Immunotherapy. J. Infect. Dis. 2017, 216, 678-687. [CrossRef] [PubMed]

153. Erickson, J.; Gilchuk, P.; Hastings, A.K.; Tollefson, S.J.; Johnson, M.; Downing, M.B.; Boyd, K.L.; Johnson, J.E.; Kim, A.S.; Joyce, S.; et al. Viral acute lower respiratory infections impair CD8+ T cells through PD-1. J. Clin. Investig. 2012, 122, 2967-2982. [CrossRef] [PubMed]

154. Erickson, J.; Rogers, M.; Hastings, A.K.; Tollefson, S.J.; Williams, J.V. Programmed death-1 impairs secondary effector lung $\mathrm{CD}^{+} \mathrm{T}$ cells during respiratory virus reinfection. J. Immunol. 2014, 193, 5108-5117. [CrossRef]

155. Hastings, A.K.; Erickson, J.J.; Schuster, J.E.; Boyd, K.L.; Tollefson, S.J.; Johnson, M.; Gilchuk, P.; Joyce, S.; Williams, J.V. Role of Type I Interferon Signaling in Human Metapneumovirus Pathogenesis and Control of Viral Replication. J. Virol. 2015, 89, 4405-4420. [CrossRef]

156. Falsey, A.R.; Hennessey, P.A.; Formica, M.A.; Criddle, M.M.; Biear, J.M.; Walsh, E.E. Humoral immunity to human metapneumovirus infection in adults. Vaccine 2009, 28, 1477-1480. [CrossRef]

157. El Najjar, F.; Cifuentes-Muñoz, N.; Chen, J.; Zhu, H.; Buchholz, U.J.; Moncman, C.L.; Dutch, R.E. Human metapneumovirus Induces Reorganization of the Actin Cytoskeleton for Direct Cell-to-Cell Spread. PLoS Pathog. 2016, 12, e1005922. [CrossRef]

158. Pan, J.; Qian, X.; Lattmann, S.; El Sahili, A.; Yeo, T.H.; Jia, H.; Cressey, T.; Ludeke, B.; Noton, S.; Kalocsay, M.; et al. Structure of the human metapneumovirus polymerase phosphoprotein complex. Nature 2019, 577, 275-279. [CrossRef] 
159. Langley, J.M.; Macdonald, L.D.; Weir, G.M.; MacKinnon-Cameron, D.; Ye, L.; McNeil, S.A.; Schepens, B.; Saelens, X.; Stanford, M.M.; Halperin, S.A. A Respiratory Syncytial Virus Vaccine Based on the Small Hydrophobic Protein Ectodomain Presented with a Novel Lipid-Based Formulation Is Highly Immunogenic and Safe in Adults: A First-in-Humans Study. J. Infect. Dis. 2018, 218, 378-387. [CrossRef]

160. Chlibek, R.; Smetana, J.; Pauksens, K.; Rombo, L.; Hoek, J.A.R.V.D.; Richardus, J.H.; Plassmann, G.; Schwarz, T.F.; Ledent, E.; Heineman, T.C. Safety and immunogenicity of three different formulations of an adjuvanted varicella-zoster virus subunit candidate vaccine in older adults: A phase II, randomized, controlled study. Vaccine 2014, 32, 1745-1753. [CrossRef]

161. Rogers, M.C.; Williams, J.V. Reining in the CD8+ T cell: Respiratory virus infection and PD-1-mediated T-cell impairment. PLoS Pathog. 2019, 15, e1007387. [CrossRef] [PubMed]

(C) 2020 by the authors. Licensee MDPI, Basel, Switzerland. This article is an open access article distributed under the terms and conditions of the Creative Commons Attribution (CC BY) license (http://creativecommons.org/licenses/by/4.0/). 